2 Impact of urban pollution on organic-mediated new particle formation and particle

3 number concentration in the Amazon rainforest

4 Bin Zhao ${ }^{*,+}$, Jerome D. Fast ${ }^{\dagger}$, Neil M. Donahue ${ }^{\ddagger}, \mathcal{\beta}, \|, \perp$, Manish Shrivastava ${ }^{\dagger}$, Meredith

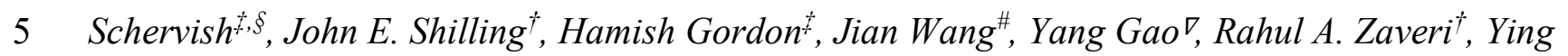

6 Liu $^{\dagger}$, Brian Gaudet ${ }^{\dagger}$

7 †Pacific Northwest National Laboratory, Richland, Washington, USA

8 Center for Atmospheric Particle Studies, Carnegie Mellon University, Pittsburgh, PA 15213, 9 USA

$10 \S^{\S}$ Department of Chemistry, Carnegie Mellon University, Pittsburgh, PA 15213, USA

11 "Department of Engineering and Public Policy, Carnegie Mellon University, Pittsburgh, PA 15213, 12 USA

$13{ }^{\perp}$ Department of Chemical Engineering, Carnegie Mellon University, Pittsburgh, PA 15213, USA

$14{ }^{\#}$ Center for Aerosol Science and Engineering, Department of Energy, Environmental and Chemical

15 Engineering, Washington University in St. Louis, Missouri, USA

$16{ }^{\nabla}$ Key Laboratory of Marine Environment and Ecology, Ministry of Education/Institute for 17 Advanced Ocean Study, Ocean University of China, Qingdao 266100, China

\title{
$19 *$ Corresponding Author
}

20 Bin Zhao Phone: +1-3109231612; e-mail: bin.zhao@pnnl.gov.

22 Number of pages: 36

23 Number of tables: 3

24 Number of figures: 13 


\section{More details of the model and its configuration}

26 The parameterizations of NPF rates were developed in several previous studies based on

27 experiments in the CLOUD (Cosmics Leaving Outdoor Droplets) chamber, ${ }^{1-4}$ with a couple of

28 updates in our previous study. ${ }^{5}$ The NPF rates at $1.7 \mathrm{~nm}$ mobility equivalent diameter are

29 calculated as the sum of the following parametrizations:

30 (1) Binary neutral (indicated by $b, n)$ and ion-induced $(b, i)$ NPF involving sulfuric acid:

$$
J_{S A}=k_{b, n}(T)\left[H_{2} S_{4}\right]^{p_{b, n}}+k_{b, i}(T)\left[H_{2} S_{4}\right]^{p_{b, i}}\left[n_{-}\right]
$$

32 where the $k(T)$ is a temperature-dependent prefactor and includes free-fitting parameters (see

33 equations below), $p$ is a constant free parameter, and $\left[n_{-}\right]$is the concentration of negative ions.

34 (2) Ternary neutral (indicated by $t, n$ ) and ion-induced $(t, i) \mathrm{NPF}$ involving sulfuric acid and $\mathrm{NH}_{3}$ :

$$
\begin{aligned}
J_{S A, N H 3}= & k_{t, n}(T) f_{n}\left(\left[\mathrm{NH}_{3}\right],\left[\mathrm{H}_{2} \mathrm{SO}_{4}\right]\right)\left[\mathrm{H}_{2} \mathrm{SO}_{4}\right]^{p_{t, n}} \\
& +k_{t, i}(T) f_{i}\left(\left[\mathrm{NH}_{3}\right],\left[\mathrm{H}_{2} \mathrm{SO}_{4}\right]\right)\left[\mathrm{H}_{2} \mathrm{SO}_{4}\right]^{p_{t, i}\left[n_{-}\right]}
\end{aligned}
$$

where the $f\left(\left[\mathrm{NH}_{3}\right],\left[\mathrm{H}_{2} \mathrm{SO}_{4}\right]\right)$ is a function of the ammonia and sulfuric acid concentrations, also involving free-fitting parameters.

All the $k(T)$ in (1) and (2), for temperatures $T$ in Kelvin, are given by:

$$
\ln k_{(x, y)}=u_{(x, y)}-\exp \left(v_{(x, y)}\left(T / 1000-w_{(x, y)}\right)\right)
$$

where $x=b$ or $t$ (binary and ternary) and $y=n$ or $i$ (neutral and ion-induced). The functions $f_{y}\left(\left[\mathrm{NH}_{3}\right],\left[\mathrm{H}_{2} \mathrm{SO}_{4}\right]\right)$ are

$$
f_{y}\left(\left[\mathrm{NH}_{3}\right],\left[\mathrm{H}_{2} \mathrm{SO}_{4}\right]\right)=\left[\mathrm{NH}_{3}\right] /\left(a_{y}+\left[\mathrm{H}_{2} \mathrm{SO}_{4}\right]^{p_{t, y}} /\left[\mathrm{NH}_{3}\right]^{p_{A, y}}\right)
$$

(3) NPF of organics with sulfuric acid:

$$
J_{S A-o r g}=k_{S A-o r g}\left[H_{2} S_{4}\right]^{2}\left(33.0 \times 0.667\left[E_{L V O C} C_{O: C>0.4}\right]\right)
$$

where $\left[E L V O C_{O: C>0.4}\right]$ refers to the concentration of ELVOC with $\mathrm{O}: \mathrm{C}>0.4$ from the oxidation of monoterpenes, and $k_{S A-o r g}$ is a fitted parameter. The factor 0.667 corrects for the large yield 
of ELVOC from $\alpha$-pinene (a type of endocyclic monoterpene) compared to other monoterpenes, as endocyclic monoterpenes comprise nearly $2 / 3$ of all monoterpene emissions over the Amazon. ${ }^{6}$

50 The adjustment factor of 33.0 is the ratio of total monoterpene oxidation products to ELVOC with

$51 \mathrm{O}: \mathrm{C}>0.4$ under the environmental conditions where the parameterizations were developed. ${ }^{5}$

52 (4) NPF from organics alone, a sum of neutral $\left(J_{n, o r g}\right)$ and ion-induced $\left(J_{\text {iin,org }}\right)$ components:

$$
J_{n, o r g}=a_{1}\left(3.6 \times 0.667\left[U L V O C_{O: C>0.4}\right]\right)^{a_{2}+a_{5} /\left(3.6 \times 0.667\left[U L V O C_{O: C>0.4}\right]\right)}
$$

4

$$
J_{\text {iin,org }}=a_{3}\left(3.6 \times 0.667\left[\operatorname{ULVOC}_{O: C>0.4}\right]\right)^{a_{4}+a_{5} /\left(3.6 \times 0.667\left[\operatorname{ULVOC}_{O: C>0.4}\right]\right)}\left[n_{ \pm}\right]
$$

55 where $\left[U L V O C_{O: C>0.4}\right]$ refers to the concentration of ULVOC with $\mathrm{O}: \mathrm{C}>0.4$ from the oxidation 56 of monoterpenes and is given here for convenience in units of $10^{7}$ molecules $\mathrm{cm}^{-3},\left[n_{ \pm}\right]$is the 57 ion concentration (equal to $\left[n_{-}\right]$, but ions of both signs participate in this NPF process), and $a_{i}$ 58 are free parameters. The factor 0.667 has the same meaning as described above. The adjustment 59 factor of 3.6 is the ratio of highly oxygenated organic molecules (HOMs) to ULVOC with O:C $60>0.4$ under the environmental conditions where the parameterizations were developed. ${ }^{5}$

61 (5) In a sensitivity simulation, we also consider the NPF of $\mathrm{H}_{2} \mathrm{SO}_{4}$ with amines. Assuming all 62 amines nucleate at the same rate as dimethylamine (DMA), the NPF rate is given by:

$$
J_{S A-\text { Amine }}=k_{S A-A m i n e-1}\left([D M A] /\left(2.5 \times 10^{7}\right)\right)\left[H_{2} S O_{4}\right]^{3.7}
$$

64 for $[D M A]>2 \times 10^{8} \mathrm{~cm}^{-3}$, and

$$
J_{S A-A m i n e}=k_{S A-A m i n e-}\left([D M A] /\left(2.5 \times 10^{7}\right)\right)^{4.36}\left[\mathrm{H}_{2} \mathrm{SO}_{4}\right]^{3.7}
$$

66 for $[D M A]<2 \times 10^{8} \mathrm{~cm}^{-3} \cdot k_{S A-A m i n e-1}$ and $k_{S A-A m i n e-}$ are fitted parameters.

67 The values of all parameters in the equations above are given in Table S1 (shown below). 68 Attention must be paid to the units of the gas concentrations, specified in the table footnotes.

69 The parameterizations above do not consider the impact of relative humidity on organic70 mediated NPF. It is not easy to investigate the impact of relative humidity on NPF during the wet 
71 season of the Amazon based on available observational data because the relative humidity is

72 almost always quite high in the boundary layer - the region this study focuses on and most

73 observational data are available in. The relative humidity within our domain is as high as

$7489.6 \pm 11.6 \%$ at the surface level and $87.5 \pm 9.2$ at $500 \mathrm{~m}$ height during our simulation period (Table

75 S3). From the laboratory perspective, $\mathrm{Li}$ et al. ${ }^{7}$ investigated the effect of relative humidity on the

76 formation of highly oxygenated organic molecules and new particles in a flow tube reactor. They

77 found that as relative humidity increases from $\sim 3 \%$ to $\sim 92 \%$, the total SOA number

78 concentrations decrease by a factor of $2-3$, suggesting that high $\mathrm{RH}$ might inhibit pure-organic

79 NPF. However, the mechanisms for this inhibition remain unclear. Also, the conclusion derived

80 from pure-organic NPF by Li et al. ${ }^{7}$ may not be directly applicable to the NPF of $\mathrm{H}_{2} \mathrm{SO}_{4}$ with

81 organics - the main NPF pathway in our region of interest. Besides, since the relative humidity in

82 the wet season of the Amazon has a relatively small variability, the effect of relative humidity on

83 NPF in this region is expected to be smaller than the effect shown by Li et al. ${ }^{7}$ Because of these

84 reasons, we do not consider the effect of relative humidity on organic-mediated NPF in our model.

85 We are interested in considering this effect when more quantitative and mechanistic experimental

86 evidence becomes available.

87 As described in the main text, we use the MOSAIC (Model for Simulating Aerosol Interaction

88 and Chemistry) aerosol module ${ }^{8}$ in our simulation. We changed the accommodation coefficient

89 for the condensation of $\mathrm{H}_{2} \mathrm{SO}_{4}$ from 0.1 in the original MOSAIC module to 1.0, following Hanson 9 .

90 The aqueous-phase chemistry is based on the Carnegie Mellon University (CMU) scheme of Fahey

91 and Pandis ${ }^{10}$. The biogenic emissions are calculated online using the Model of Emissions of Gases

92 and Aerosols from Nature (MEGAN v2.1) ${ }^{11}$ that has been recently coupled within the land surface

93 scheme CLM4 in WRF-Chem. ${ }^{12}$ We reduce the monoterpene emissions predicted by MEGAN 
94 v2.1 by a factor of 2 so that the simulated magnitude of monoterpene concentrations generally

95 agrees with aircraft observations (see the main text). A previous modeling study over the Amazon

96 also suggested that the simulated monoterpene concentrations using MEGAN v2.1 overpredicted

97 observations by about a factor of $2 \cdot{ }^{13}$ The vertical resolution of the simulation includes 45 layers

98 from the surface to $50 \mathrm{hPa}$ with denser layers at lower altitudes. The physical options, as well as

99 initial and boundary conditions used in our simulations, follow Zhao et al. ${ }^{5}$

100 2. Sources of observational data

101 We evaluate the model simulations using measurements obtained in the GoAmazon

102 (Observations and Modelling of the Green Ocean Amazon) campaign. ${ }^{14-16}$ The pollution plumes

103 from Manaus generally follow the easterly trade winds during the simulation period. The

104 Gulfstream 1 (G-1) aircraft was deployed during certain days of the GoAmazon campaign to

105 measure aerosol characteristics downwind (west) of Manaus. As described in the main text, on

106 March 11, 13, and 14, the aircraft flight track passed over Manaus or intersected its pollution plume

107 perpendicular to the prevailing wind direction $4-5$ times (Transects $\mathrm{P} 0$ to $\mathrm{P} 3 / 4$ in Fig. 1) at

108 increasing distances from Manaus at an altitude of 500-800 m. Based on the average wind speed

109 in the plume, on March 11, the transport times from Transect P0 (right above Manaus) to Transects

$110 \mathrm{P} 1, \mathrm{P} 2$, and P3 are about $1.26 \mathrm{~h}, 2.34 \mathrm{~h}$, and $3.77 \mathrm{~h}$, respectively. On March 13, the transport times

111 from P0 to P1, P2, P3, and P4 are about 1.15 h, 2.26 h, 3.45 h, and 4.78 h, respectively. On March

112 14, the transport times from $\mathrm{P} 0$ to $\mathrm{P} 1, \mathrm{P} 2, \mathrm{P} 3$, and $\mathrm{P} 4$ are about $1.06 \mathrm{~h}, 2.08 \mathrm{~h}, 2.71 \mathrm{~h}$, and $4.28 \mathrm{~h}$,

113 respectively. On March 12, the flight is special in that the plume transects were made in the

114 southernmost parts of the flight tracks (cf. middle parts for other flights) and turn-around flight

115 legs were made to achieve more effective plume transects; the aircraft still periodically passed

116 through in-plume and background air but Transects P0-P3 are not located increasingly farther 
117 downwind as in other flights (see Fig. 1). We use total particle number concentrations measured

118 by a condensation particle counter (CPC, TSI model 3025, cutoff diameter $3 \mathrm{~nm}$ ) and particle size

119 distributions ranging from $10 \mathrm{~nm}$ to $400 \mathrm{~nm}$ in diameter characterized by a fast integrated mobility

120 spectrometer (FIMS) at a time resolution of 1 second. ${ }^{15,17}$ We also make use of monoterpene

121 concentrations measured by an Ionicon quadrupole high-sensitivity proton-transfer-reaction mass

122 spectrometer (PTR-MS) onboard G-1. ${ }^{16}$ Moreover, we employ measurements of $\mathrm{H}_{2} \mathrm{SO}_{4}$ by a

123 hydroxyl radical chemical ionization mass spectrometer (CIMS) at the T3 surface site downwind

124 of Manaus (Fig. 1) - the only available $\mathrm{H}_{2} \mathrm{SO}_{4}$ measurements during the GoAmazon campaign. ${ }^{18}$

125 Particle number concentration measurements at the $\mathrm{T} 1$ surface site in the urban area of Manaus

126 are not available for the simulation period (March 6-15, 2014). Therefore, we employ the

127 measurements during March 6-15 of 2016 made by a scanning mobility particle sizer (SMPS, TSI

128 model 3081) for particles with a diameter of $10-450 \mathrm{~nm}$ and conduct additional simulations with

129 exactly the same model configurations during this period to compare with the measurements. Note

130 that the CPC and FIMS aboard the G-1 aircraft and the SMPS at the T1 site are all located behind

131 a dryer. As a result, the sampling relative humidity has remained less than $40 \%$ for the whole field

132 campaign, which effectively minimized the potential impact of ambient relative humidity or water

133 supersaturation. For $\mathrm{NH}_{3}$, no available observations are found within the modeling domain, thus

134 we use $\mathrm{NH}_{3}$ concentration measurements by a wet-annular denuder at a site in southwest Amazon

135 during the wet season of $2002^{19}$ as a proxy.

\section{3. Supplementary information about model-observation comparison}

137 In the main text, we compared simulated vs. observed particle size distributions (Fig. 3). Since 138 this comparison is limited to particles larger than $10 \mathrm{~nm}$ in diameter due to the limitation of FIMS, 139 we further show in Fig. S11 observed particle number concentrations in the diameter range of 3- 
$14010 \mathrm{~nm}$ by the G-1 aircraft as well as simulated concentrations during four flights on March 11-14.

141 The observed particle number concentrations between $3 \mathrm{~nm}$ and $10 \mathrm{~nm}$ are derived from the

142 difference between two CPCs that measure particles larger than $3 \mathrm{~nm}$ and $10 \mathrm{~nm}$, respectively.

143 First, we note that the observed high numbers of particles between 3 and $10 \mathrm{~nm}$ in the plumes

144 do indeed confirm that a large fraction of the particle concentrations is probably contributed by

145 NPF. Without NPF, the primarily emitted particles would have grown to larger sizes when they

146 were transported to the locations where they were observed by the G-1 aircraft (see the blue lines

147 in Fig. 3).

148 Second, we compare the modeled and observed concentrations. It is very challenging for

149 mainstream models to capture the particle distribution below $10 \mathrm{~nm}$ because such small particles

150 are very sensitive to even small changes in condensational growth and coagulational scavenging.

151 In our base-case simulation ("inorg+org_R2D-VBS"), the model captures the peak number

152 concentration in the range of $3-10 \mathrm{~nm}$ in some of the transects but generally underestimates the

153 peak concentrations in most transects. One likely reason for this bias is that the current model

154 assumes instantaneous equilibrium for gas-particle partitioning of organics instead of considering

155 kinetic partitioning for aerosol growth processes. ${ }^{20,21}$ Another possible reason is that we used a

156 highly condensed 2-bin Volatility Basis Set (VBS) approach to simulate the SOA formation from

157 all precursors other than monoterpenes, including anthropogenic volatile organic compounds

158 (VOC), non-monoterpene biogenic VOC, evaporated primary organic aerosol (POA), and

159 intermediate volatility organic compounds (IVOC). In this simplified scheme, the oxidation

160 products from each type of precursor are assumed to possess the same volatility $\left(\mathrm{C}^{*}\right.$ of $0.01 \mu \mathrm{g}$

$161 \mathrm{~m}^{-3}$ for the oxidation products of evaporated POA and IVOC and $1.0 \mu \mathrm{g} \mathrm{m}^{-3}$ for the oxidation

162 products from anthropogenic VOC and non-monoterpene biogenic VOC), which may bias the size- 
163 dependent growth rates. For example, Zaveri et al. ${ }^{22}$ recently showed that assuming the

164 condensable vapors to have low volatility may cause small particles to grow too fast and thus lead

165 to underestimation of the concentration of small particles. In our ongoing work, we are trying to

166 incorporate kinetic organic partitioning in WRF-Chem and simulate the non-monoterpene organic

167 chemistry using an updated 4-bin VBS from Shrivastava et al. ${ }^{13}$, which we hope will alleviate the

168 underestimation of particles between $3 \mathrm{~nm}$ and $10 \mathrm{~nm}$.

169 To show that the above bias should not affect the main conclusion of this study regarding the

170 source of particle number, we conduct two sensitivity simulations in which we artificially reduce

171 the particle growth rate either in the entire size range ("slow growth") or only in the size range

172 below $10 \mathrm{~nm}$ ("slow growth below $10 \mathrm{~nm}$ ") to allow more particles to stay in the range of 3-10

$173 \mathrm{~nm}$. Specifically, we assume that only 50\% (cf. 100\% in the base-case simulation) of the excessive

174 organic vapor (i.e., gas concentration before partitioning - equilibrium gas concentration) will

175 condense to the particle phase in the specified size range in each time step. Fig. S11 shows that

176 both scenarios show higher particle number concentrations between $3 \mathrm{~nm}$ and $10 \mathrm{~nm}$ compared to

177 the base-case simulation, leading to a much closer agreement with observations, though biases still

178 exist. Fig. S12 further illustrates the fractional contribution of NPF within the modeling domain to

179 particle number concentrations on a 2-km high vertical cross section which extends westward from

180 Manaus to $200 \mathrm{~km}$ downwind in the base case and two sensitivity scenarios. The contribution of

181 NPF is quantified using the difference in simulated particle concentrations between one of the

182 three scenarios and a hypothetical scenario without NPF ("nonuc" in Table S2). All three scenarios

183 show similar relative contributions of NPF to particle number concentration in the areas downwind

184 of Manaus, suggesting that the bias in particle growth that leads to the underestimation of 3-10 nm 
185 particles in our current model is not likely to affect our main conclusion that NPF makes the most 186 important contribution to particle number in most of the downwind areas.

187 We note that the particle number concentrations $(>3 \mathrm{~nm})$ for the "inorg" scenario are sometimes 188 lower than those for the "nonuc" scenario, as shown in Fig. 2. This is probably because the changes 189 in aerosol fields due to inorganic NPF could affect the meteorological fields by interacting with 190 radiation and clouds, which may further perturb particle concentrations at other times and 191 locations. Since the rates of inorganic NPF are small at many times and locations, the accumulated 192 perturbation over time could dominate over the direct particle formation in some circumstances, 193 leading to occasional lower particle number concentrations in the "inorg" scenario than in the 194 "nonuc" scenario. We also note that the simulated particle number at P3 on March 11 is 195 significantly lower than the observed value (Fig. 3a). The main reason is that the simulated 196 centerline of the pollution plume was shifted to some extent relative to the observed location (see 197 Fig. 2a), probably because of uncertainties in the simulated wind direction. As a result, the model 198 underestimates observed particle number concentrations near the location of the observed pollution 199 plume centerline.

200 As mentioned in the main text, we conduct additional simulations with the same model 201 configurations for March 6-15 in 2016 to compare with measurements at the T1 site. Here we 202 calculate the statistics of major meteorological variables within the modeling domain at the surface 203 level and $500 \mathrm{~m}$ height during our main simulation period (March 6-15, 2014) and the above 204 supplementary simulation period, as summarized in Table S3. The temperature and relative 205 humidity are very similar during the two simulation periods. The wind speed is also similar- the 206 mean wind speed is slightly larger in the simulation period of 2014 but the standard deviation is 207 very close in the two periods. The size distribution simulated by the base case ("inorg+org_R2D- 
208 VBS") generally agrees with observations at T1, with a certain level of overestimation in the range

209 of 20-60 nm and underestimation in smaller and larger sizes (Fig. S4). As we discussed above, we

210 expect that the size distribution could be further improved after we incorporate in WRF-Chem

211 kinetic particle growth and improved volatility distribution of organic aerosols in our ongoing

212 work.

\section{4. Relationships between NPF rates and particle number concentrations}

214 The NPF rates shown in Fig. 5 and Fig. S6 are relatively low compared to many field

215 observations ${ }^{23,24}$ because they are averaged during the entire simulation period (March $6-15$,

216 2014) and the data in Fig. 5 are further vertically averaged below $2 \mathrm{~km}$. In contrast, observational

217 studies usually report only the NPF rates during strong NPF events. ${ }^{23,}{ }^{24}$ Fig. S13c shows hourly

218 average NPF rates on a 2-km high vertical cross section that extends westward from Manaus to

$219200 \mathrm{~km}$ downwind during the simulation period. We can see that high hourly average NPF rates

220 larger than $10 \mathrm{~cm}^{-3} \mathrm{~s}^{-1}$ are frequently simulated by the model.

221 We have also conducted additional analysis on the relationships between NPF rates and particle

222 number concentrations, as shown in Fig. S13. Fig. S13a exhibits the time-averaged NPF rate on

223 the aforementioned vertical cross section and Fig. S13b exhibits the time-averaged particle number

224 concentration increase due to NPF, which is quantified using the difference between the base case

225 ("inorg+org_R2D-VBS") and the scenario without NPF ("nonuc"). Fig. S13c further shows hourly

226 average NPF rate and increased particle number concentration on the cross section. The increased

227 particle number concentrations due to NPF are generally larger in areas with larger NPF rates.

228 There is a statistically significant positive correlation between the two with a correlation

229 coefficient of 0.619 and a p-value $<0.001$ (Fig. S13c). However, the relationships are complicated

230 by two factors. First, a large NPF rate is simulated at the surface of the city center but the increase 
231 in particle number concentration is relatively small mainly because of a large coagulational loss

232 caused by direct particle emissions. Second, particles observed in a certain location are not

233 necessarily formed locally but may be transported from upwind areas by the prevailing easterly

234 wind. As a result of the two factors, the increased particle number concentrations due to NPF peak

235 about $30 \mathrm{~km}$ downwind of the city center while the NPF rates peak near the city center (Fig.

236 S13a,b). Also, as a result of the two factors, the increase in particle number concentrations has a

237 large variability even for a given NPF rate (Fig. S13c).

\section{5. Details of the sensitivity analysis}

239 We showed in Results and Discussion that primary particle emissions only account for a small 240 fraction of particle number concentration downwind of Manaus. Compared with the particle size

241 distribution used in many previous regional modeling studies, ${ }^{25-29}$ the size distribution used in this

242 study results in relatively large total particle number emissions (see Methods and Data). To test

243 potential uncertainties that may lead to even higher particle number emissions and hence a larger

244 contribution to ambient particle number concentrations, we design two sensitivity scenarios by

245 perturbing the total mass emissions ("nonuc_emis*4") and size distribution ("nonuc_emis_finer")

246 on the basis of the scenario without any NPF ("nonuc"). In the "nonuc_emis*4" scenario, we

247 increase the primary particle mass emissions by a factor of 4 while keeping the size distribution

248 unchanged. The particle size distribution used in this study is a superposition of two lognormal

249 distributions with an Aitken mode and an accumulation mode. In the "nonuc_emis_finer" scenario,

250 we reduce the Aitken-mode median diameter of urban sources from $25 \mathrm{~nm}$ to $12 \mathrm{~nm}$. The reason

251 is that some emission measurements suggested that the primary particles from certain types of

252 vehicles might have a peak diameter of $10-25 \mathrm{~nm},{ }^{30-32}$ smaller than $25 \mathrm{~nm}$ assumed for urban

253 emissions in this study. While the effective particle size of emissions at a 10-km grid spacing will 
254 be larger than that of fresh emissions (see Methods and Data) and thus the effective size is unlikely

255 as small as $12 \mathrm{~nm}$, we use this small size as a sensitivity test to examine the potential upper bound

256 of particle number emissions. Particle measurements at the T1 surface site in urban Manaus

257 provide a useful constraint for the estimate of primary particle emissions. Figure S3 shows that

258 both sensitivity scenarios overestimate the particle number concentration at the T1 site by a factor

259 of 2.5-3.2 even without considering NPF. This indicates that the particle number emissions in

260 these two scenarios are likely too high. Even so, Fig. S8 shows that the model still substantially

261 underestimates the aircraft-measured particle number concentration in the Manaus plumes by

262 nearly one order of magnitude. These results indicate that, even with the potential upper bound of

263 the particle number emission estimates, the primary particle emissions are not likely the main

264 sources for the high particle number concentrations in the pollution plumes from Manaus.

265 Apart from primary emissions, our results also indicate that inorganic NPF pathways make a

266 minor contribution to particle number downwind of Manaus. To investigate the factors that could

267 potentially lead to a larger contribution from inorganic NPF, we conduct two additional sensitivity

268 simulations ("inorg_ $\mathrm{NH}_{3} * 3$ " and "inorg_amine") based on the scenario of "inorg". Among the

269 precursors for inorganic $\mathrm{NPF}$, the concentrations of $\mathrm{NH}_{3}$ are subject to a relatively large

270 uncertainty partly due to very limited measurements over the Amazon. The "inorg_ $\mathrm{NH}_{3} * 3$ "

271 scenario is the same as "inorg" except that the $\mathrm{NH}_{3}$ concentrations are elevated by a factor of 3.

272 The NPF of $\mathrm{H}_{2} \mathrm{SO}_{4}$ and amines has also been shown to be an appreciable pathway in certain

273 polluted environments. ${ }^{33,34}$ In the "inorg_amine" scenario, we provide a first-order estimate of the

274 potential contribution of $\mathrm{H}_{2} \mathrm{SO}_{4}+$ amine NPF by incorporating the parameterization developed by

275 Dunne et al. ${ }^{1}$ using data from the CLOUD chamber. ${ }^{35}$ The amine concentrations have been

276 modeled by several studies with very similar methods; they all derived the amine emission 
277 inventory by scaling down ammonia emissions using sector-specific factors. ${ }^{1,36,37}$ Here we apply

278 the ratio of amine concentration to ammonia concentration simulated by Dunne et al. ${ }^{1}$ over our

279 domain to the WRF-Chem/R2D-VBS simulated ammonia concentrations to estimate the amine

280 concentrations, and subsequently use the estimated amine concentrations to calculate the

$281 \mathrm{H}_{2} \mathrm{SO}_{4}+$ amine NPF rate. Note that this scenario merely serves as a rough estimate of the potential

282 contribution of amines rather than a rigorous quantification of the NPF rate. Figure S9 reveals that

283 both the "inorg_ $\mathrm{NH}_{3} * 3$ " and "inorg_amine" scenarios only slightly amplify simulated particle

284 number concentrations relative to "inorg", which are still far below the concentrations observed

285 by the G-1 aircraft. These results reinforce our findings that inorganic NPF is unlikely the main

286 source of the particle number downwind of Manaus and suggest that our conclusions are robust.

287 The above sensitivity simulations, by testing the potential upper bounds of primary particle 288 emissions and inorganic NPF, increase our confidence that organic-mediated NPF probably acts 289 as the most important source of particle number downwind of Manaus. A sophisticated model 290 representation of organic-mediated NPF is crucially important for reasonably estimating its 291 contribution in polluted environments. Here we conduct two sensitivity simulations to show that 292 previous more simplified model treatments may lead to substantial bias in simulated NPF rates. In 293 the first simulation ("inorg+org_simple"), we assume that the organics contributing to NPF are a 294 fixed fraction of all monoterpene oxidation products, following the common practice of many 295 previous studies. ${ }^{1,4,27,38-40}$ The specific fixed fractions we used are from Gordon et al. ${ }^{4}$ Figure S10 296 shows that this sensitivity run overestimates the G-1 observed particle number concentrations in 297 Manaus plumes by 1-1.5 orders of magnitude. A major reason, among others, is that this simple 298 treatment fails to capture the strong condensation sink of ULVOC/ELVOC in pollution plumes 299 due to their extremely low volatilities. In another sensitivity scenario ("inorg+org_R2D- 
300 VBS_uniauto"), we apply an older version of the Radical 2D-VBS used in Zhao et al. ${ }^{5}$ The

301 difference between the two versions is that the older version used a uniform autoxidation rate for

302 all $\mathrm{RO}_{2}$ of the same generation. Figure $\mathrm{S} 10$ reveals that this scenario significantly underestimates

303 peak particle number concentrations in Manaus plumes by over one order of magnitude, indicating

304 that the prompt ELVOC formation through rapid autoxidation is critically important to effectively

305 compete with the condensation loss in urban plumes and to produce a considerable number of new

306 particles. While a uniform autoxidation rate can reasonably simulate the particle formation in

307 pristine conditions, ${ }^{5}$ an appropriate representation of diversity in ELVOC formation rate is

308 necessary for polluted regions with a large condensation loss. The inorganic species involved in

309 NPF comprise a relatively small set; the organics are numerous, spanning a wide range in volatility

310 and also reactivity. The Radical 2D-VBS represents a substantial simplification over a full

311 chemical description. Our results reveal that further reducing the complexity much beyond this

312 point introduces measurable errors into real-world model outputs.

\section{6. Discussion of the potential impact of other precursors and processes}

314 In our current model, we use monoterpenes as the main precursors to drive organic-mediated

$315 \mathrm{NPF}$, because monoterpenes have been well recognized to be an important contributor to NPF

316 since the oxidation of monoterpene produces a significant amount of ULVOC and ELVOC. It is

317 noted, however, that other organic precursors may also have (enhancement or suppression) effects

318 on NPF.

319 In contrast to monoterpenes, isoprene has been much less frequently observed to trigger $\mathrm{NPF}^{41}$

320 but has been frequently shown to suppress NPF events. ${ }^{42-44}$ Regarding NPF triggered by isoprene,

321 Inomata et al. ${ }^{41}$ showed that the ozonolysis of isoprene produces stabilized Criegee intermediates

322 and subsequently oligomeric hydroperoxides, which contribute to NPF under dry conditions. 
323 However, the isoprene concentrations used in that experiment ( $\sim 2 \mathrm{ppm})$ are approximately 3 orders

324 of magnitude higher than the isoprene concentrations observed in our region of interest $(0.43-2.37$

$325 \mathrm{ppb}) .{ }^{16}$ Besides, Inomata et al. ${ }^{41}$ showed that the NPF triggered by isoprene oxidation products is

326 substantially suppressed when relative humidity is larger than $68 \%$. The relative humidity within

327 our domain is as high as $89.6 \pm 11.6 \%$ at the surface level and $87.5 \pm 9.2$ at $500 \mathrm{~m}$ height during our

328 simulation period (Table S3), which is high enough to largely suppress isoprene-induced NPF.

329 Compared with the limited evidence for NPF driven by isoprene, more studies have revealed that

330 isoprene suppresses the NPF triggered by monoterpene oxidation products ${ }^{42-44}$ probably because

331 isoprene reduces the yield of highly-oxygenated dimers with about 20 carbon atoms that drive NPF

332 while increasing the production of "heterodimers" with about 15 carbon atoms (isoprene-

333 monoterpene cross reaction products). ${ }^{44}$ For these reasons, we conclude that isoprene is not likely

334 to play a dominant role in driving NPF over the Amazon, but future research is still needed to

335 quantify the effects of isoprene on NPF rates. In addition, some studies have reported that

336 sesquiterpenes might make a noticeable contribution to NPF despite their much smaller

337 concentrations than monoterpenes, ${ }^{45}$ but it is still difficult to accurately quantify their contribution

338 based on currently limited results. More recently, it was found that the oxidation of anthropogenic

339 organic precursors may also produce oxidation products with sufficiently low volatility to trigger

340 NPF in polluted environments. ${ }^{46,47}$ For example, Wang et al. ${ }^{47}$ showed that the oxidation products

341 of toluene have a similar volatility distribution to that of $\alpha$-pinene oxidation products, while the

342 oxidation products of naphthalene are even less volatile than those from toluene or $\alpha$-pinene. Their

343 importance for NPF relative to biogenic precursors, however, remain largely unknown because 1)

344 the yields of ULVOC/ELVOC from anthropogenic precursors remain unclear; and 2) a large

345 fraction of the ULVOC/ELVOC from these precursors is produced by slower multi-generational 
346 oxidation reactions (relative to the rapid autoxidation in the case of monoterpenes), while a rapid

347 formation of ULVOC/ELVOC is important to effectively compete with the strong condensation

348 loss in polluted areas. The net organic NPF rate in the real world is likely a combined effect of all

349 aforementioned precursors, with some precursors accelerating while others slowing down the NPF

350 rates given by our current model.

351 In addition to the NPF rate, the growth and removal of particles also affect the ambient particle

352 number. After ELVOC, most typically multifunctional hydroperoxides formed via autoxidation,

353 partition to the particle phase, they may undergo further particle-phase reactions, including

354 accretion reactions leading to oligomers and decomposition leading to shorter-chain compounds. ${ }^{48,}$

35549 Pospisilova et al. ${ }^{48}$ suggested that the particle-phase reactions in $\alpha$-pinene ozonolysis

356 experiments are likely dominated by the decomposition of reactive oxygen species, including

357 hydroperoxides. The lifetimes of these species against particle-phase reactions could span a large

358 range, ${ }^{49}$ but are mostly about 30 to 150 min for $\alpha$-pinene ozonolysis products. ${ }^{48}$ The particle-phase

359 reactions result in continuous concentration and composition changes of SOA. The effect on NPF

360 remains unclear. The decomposition reaction might accelerate the evaporation of newly formed

361 particles and reduce the effective NPF rate; however, it is more likely that decomposition could

362 slow the growth rate of newly formed particles but not lead to complete evaporation. Even that is

363 uncertain. Decomposition products will not necessarily evaporate, and our results show that the

364 overall environment in the pollution plume is dominated by SOA formation and particle growth.

365 Thus, the particle-phase reactions are not likely to greatly change the NPF rate. Nevertheless,

366 future studies are needed to quantify the effect of particle-phase reactions on SOA and NPF in our

367 model. Furthermore, while our current model simulates the particle growth by condensation of

368 organics using an equilibrium partitioning method, recent studies showed that the growth and 
369 evaporation kinetics can affect the size distribution evolution ${ }^{20,21}$ and thus needs to be considered

370 in future studies to better simulate the particle growth and size distribution in the pollution plumes.

371 For example, the diameter of the simulated peak number concentration grows slower than observed

372 as show in Fig. 3. The underestimate of particles in the range of 3-10 nm may also be partly

373 attributed to this issue (see more in Section 3 of SI). Finally, the chemical loss of organic particles

374 via photolysis ${ }^{50}$ also needs to be accounted for to properly simulate the lifecycle and budget of 375 particles.

\section{7. Discussion of the role of $\mathrm{H}_{2} \mathrm{SO}_{4}$ monomer and dimer}

$377 \mathrm{H}_{2} \mathrm{SO}_{4}$ dimer is an important intermediate for many types of NPFs involving $\mathrm{H}_{2} \mathrm{SO}_{4}$. For acid378 base nucleation, such as the nucleation of $\mathrm{H}_{2} \mathrm{SO}_{4}$ with amine or $\mathrm{NH}_{3}, \mathrm{H}_{2} \mathrm{SO}_{4}$ dimer plays a key 379 role in the nucleation process. ${ }^{35,51}$ For the nucleation of $\mathrm{H}_{2} \mathrm{SO}_{4}$ with organics, the main NPF 380 pathway in our region of interest, the situation is more complex. According to the mass defect 381 diagrams for negatively charged clusters during NPF experiments involving $\mathrm{H}_{2} \mathrm{SO}_{4}$ and organics 382 at the CLOUD chamber (Fig. 2a of Riccobono et al. ${ }^{2}$ and Fig. 1c of Schobesberger et al. ${ }^{52}$ ), there 383 are many clusters of $\mathrm{H}_{2} \mathrm{SO}_{4}$ dimer with organics but there are even more clusters of $\mathrm{H}_{2} \mathrm{SO}_{4}$ 384 monomer with organics. This indicates that the $\mathrm{H}_{2} \mathrm{SO}_{4}$ dimer is likely to play a certain but not the 385 most important role in the nucleation of $\mathrm{H}_{2} \mathrm{SO}_{4}$ with organics. 

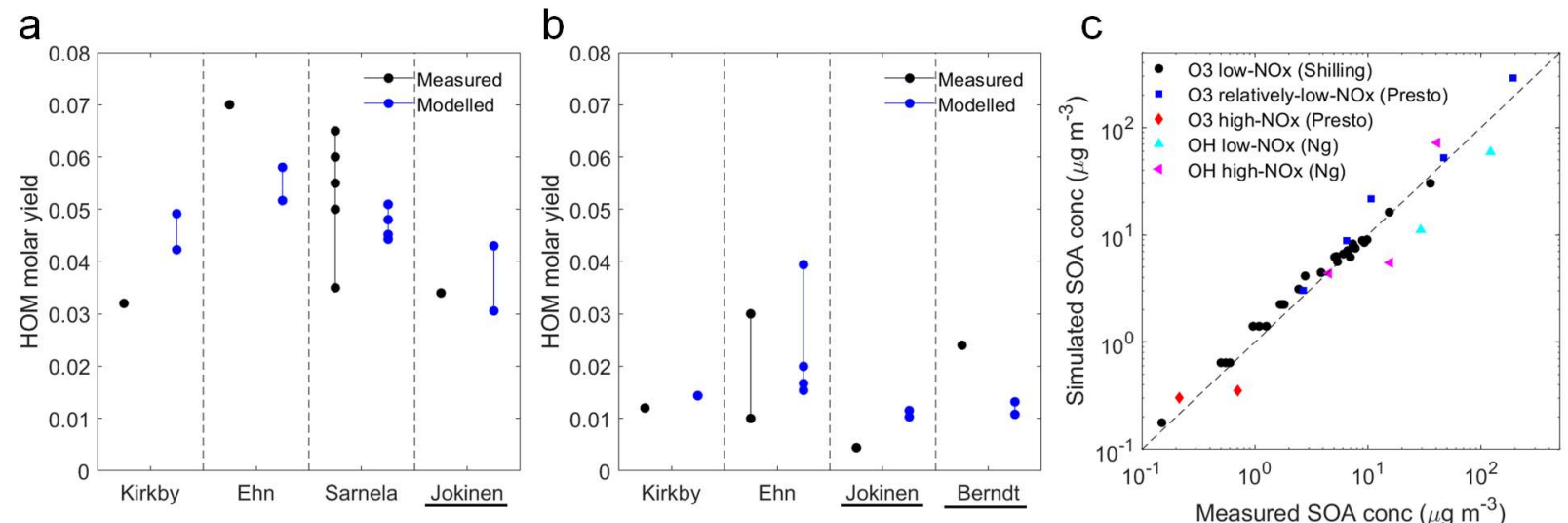

Figure S1. Comparison of Radical 2D-VBS simulated HOM yields and SOA concentrations with smog-chamber and flow-tube experiments: (a) HOM molar yields from $\alpha$-pinene $+\mathrm{O}_{3}$, (b) $\mathrm{HOM}$ molar yields from $\alpha$-pinene $+\mathrm{OH}$, and (c) SOA concentrations. The simulation results are obtained with the final Radical 2D-VBS parameters used in our 3-D simulations. The measurements of $\alpha$ pinene $+\mathrm{O}_{3} \mathrm{HOM}$ molar yields are from Kirkby et al. ${ }^{3}$, Ehn et al. ${ }^{53}$, Sarnela et al. ${ }^{54}$, and Jokinen et al. ${ }^{6}$; the measurements of $\alpha$-pinene $+\mathrm{OH}$ HOM molar yields are from Kirkby et al. ${ }^{3}$, Ehn et al. ${ }^{53}$, Jokinen et al. ${ }^{6}$, and Berndt et al. ${ }^{55}$; and the measurements of SOA concentrations are from Shilling et al. ${ }^{56}$, Presto and Donahue ${ }^{57}$, and $\mathrm{Ng}$ et al. ${ }^{58}$. In (a) and (b), each dot represents the measured HOM yield for an experiment or the simulated HOM yield for a model run (see a list of all model runs in Table S2 and S3 of Zhao et al. ${ }^{5}$ ). For some studies (Kirkby, Ehn, and Jokinen in (a); Kirkby, Jokinen, and Berndt in (b)), we only show one dot for measurements because the corresponding literature only reports the mean HOM yield for all experiments. The studies highlighted with an underline are flow-tube experiments.

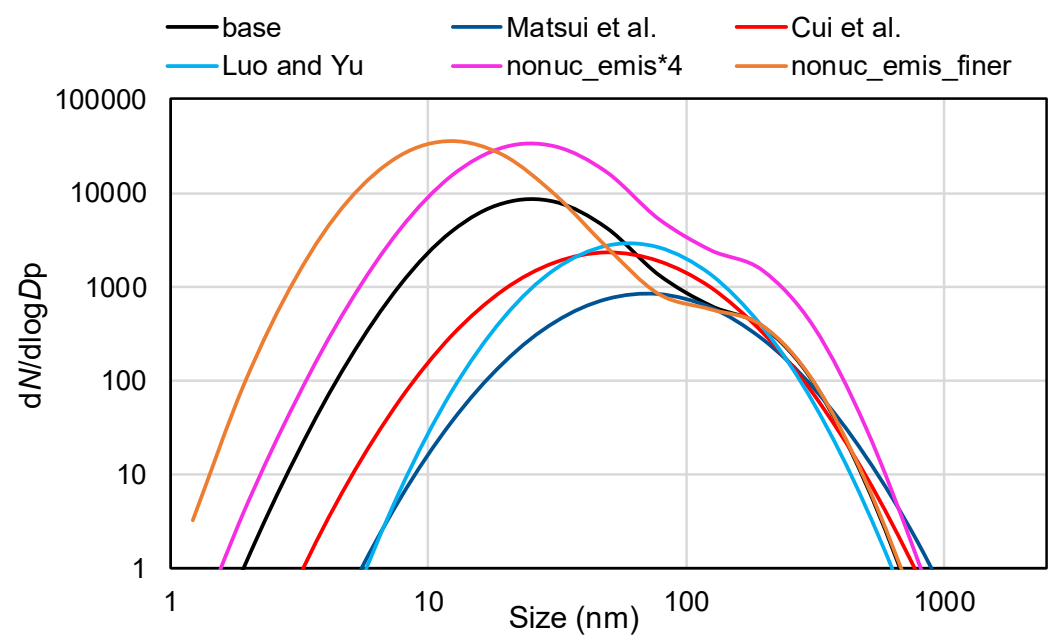

Figure S2. Number density per pg $\left(10^{-12} \mathrm{~g}\right)$ of primary particle emissions, according to the size distribution used in the base case of this study ("base" in the figure), a number of previous regional modeling studies ("Matsui et al.", "Cui et al.", and "Luo and Yu"), and two sensitivity cases in this study ("nonuc_emis*4" and "nonuc_emis_finer"). For the "nonuc_emis*4" case, the figure shows the number density per 4 pg of primary particle emissions. The size distribution of "Matsui et al." has been used in Matsui et al. ${ }^{25}$; "Cui et al." has been used in Cui et al. ${ }^{26}$ and Lupascu et 
al. ${ }^{27}$; "Luo and $\mathrm{Yu}$ " has been used in Luo and $\mathrm{Yu}^{28}$, Yu et al. ${ }^{59}$, Chen et al. ${ }^{60}$, and Chen et al. ${ }^{29}$. 410 Note that in the base case and the two sensitivity cases ("nonuc_emis*4" and "nonuc_emis_finer"), 411 we assume the mass fraction of Aitken-mode particles to be $30 \%$ ( $\mathrm{cf}$. the baseline estimate of $10 \%$ 412 in Elleman and Covert ${ }^{61}$ ) for non-industrial urban sources in Manaus, which represents an urban 413 environment with a relatively high contribution from transportation emissions.

414

415

416

417

418 419

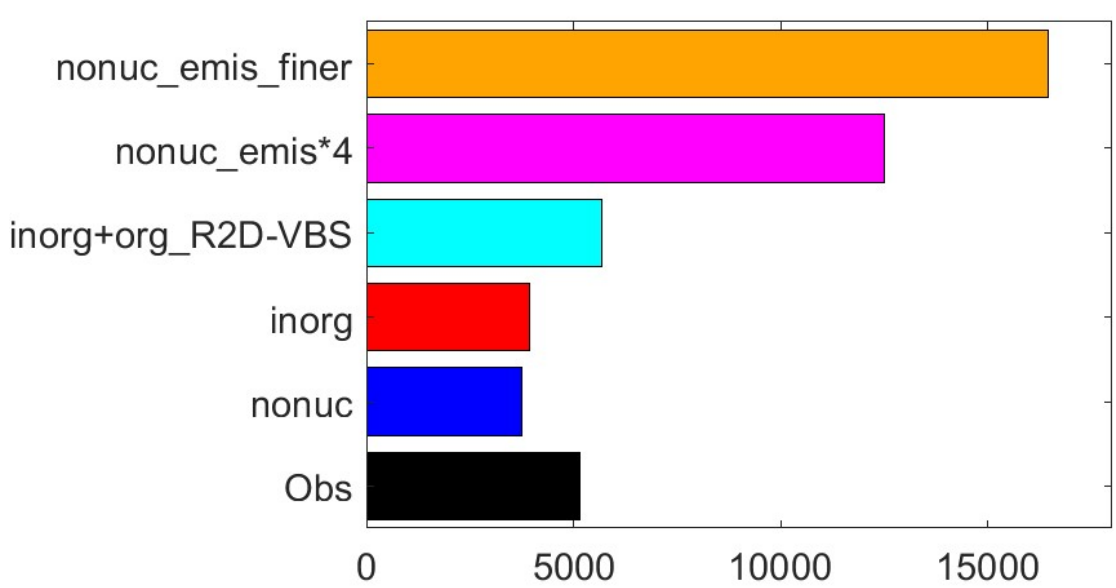

\section{Number concentration $\left(\# \mathrm{~cm}^{-3}\right)$}

Figure S3. Comparison of simulated particle number concentrations $(>10 \mathrm{~nm})$ averaged during March 6-15, 2016 with surface observations at the T1 site. The number concentrations are normalized to STP. The definitions of the model scenarios are summarized in Table S2.

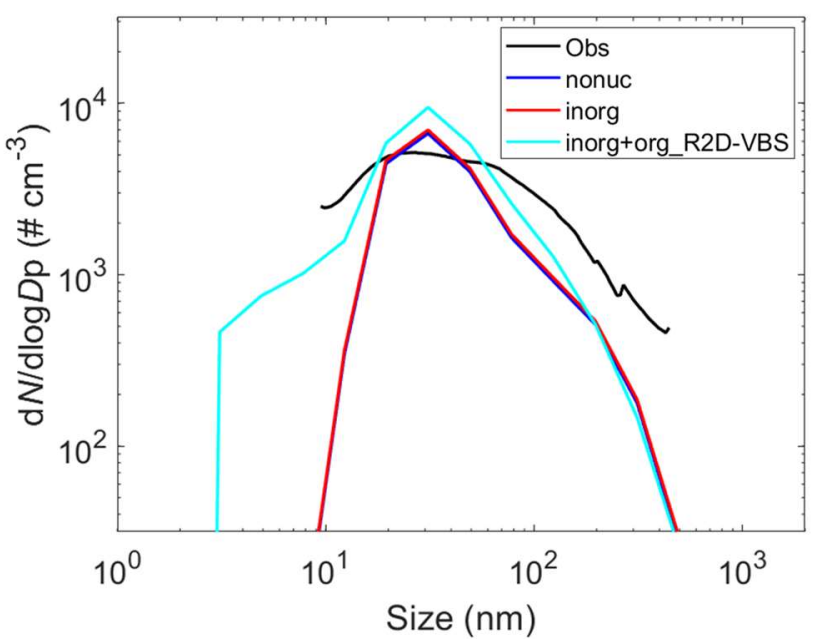

Figure S4. Comparison of simulated particle number size distribution with surface observations at the T1 site during March 6-15, 2016. The particle size distributions are normalized to STP. The definitions of the model scenarios are provided in the main text and Table S2. 


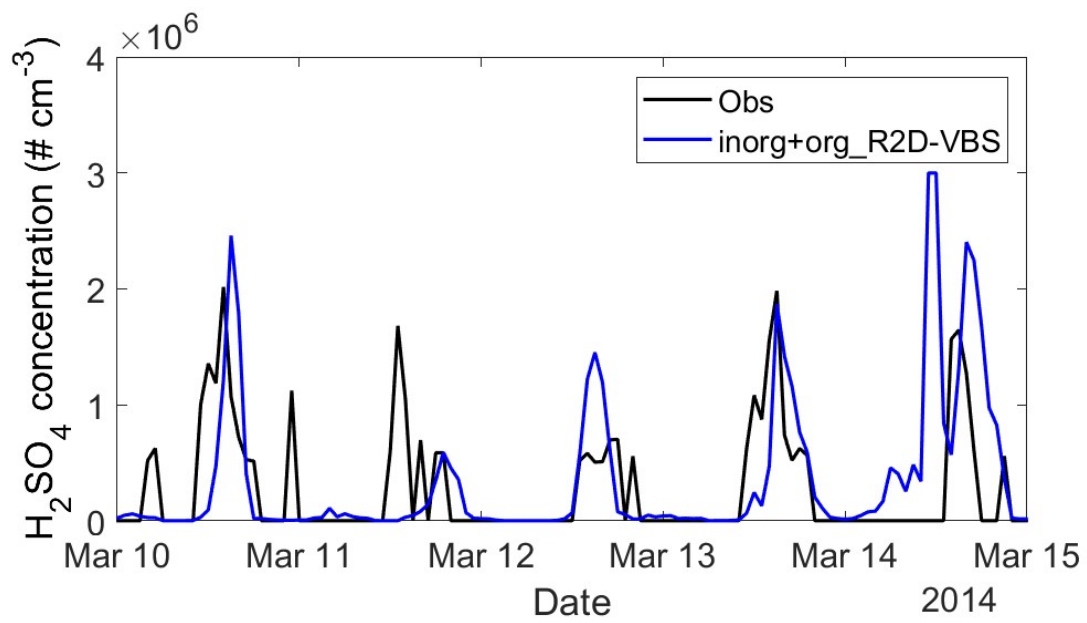

425

426

427

Figure S5. Comparison of simulated $\mathrm{H}_{2} \mathrm{SO}_{4}$ concentrations simulated by the base case ("inorg+org_R2D-VBS") with surface observations at the T3 site. The concentrations are 428 normalized to STP. 

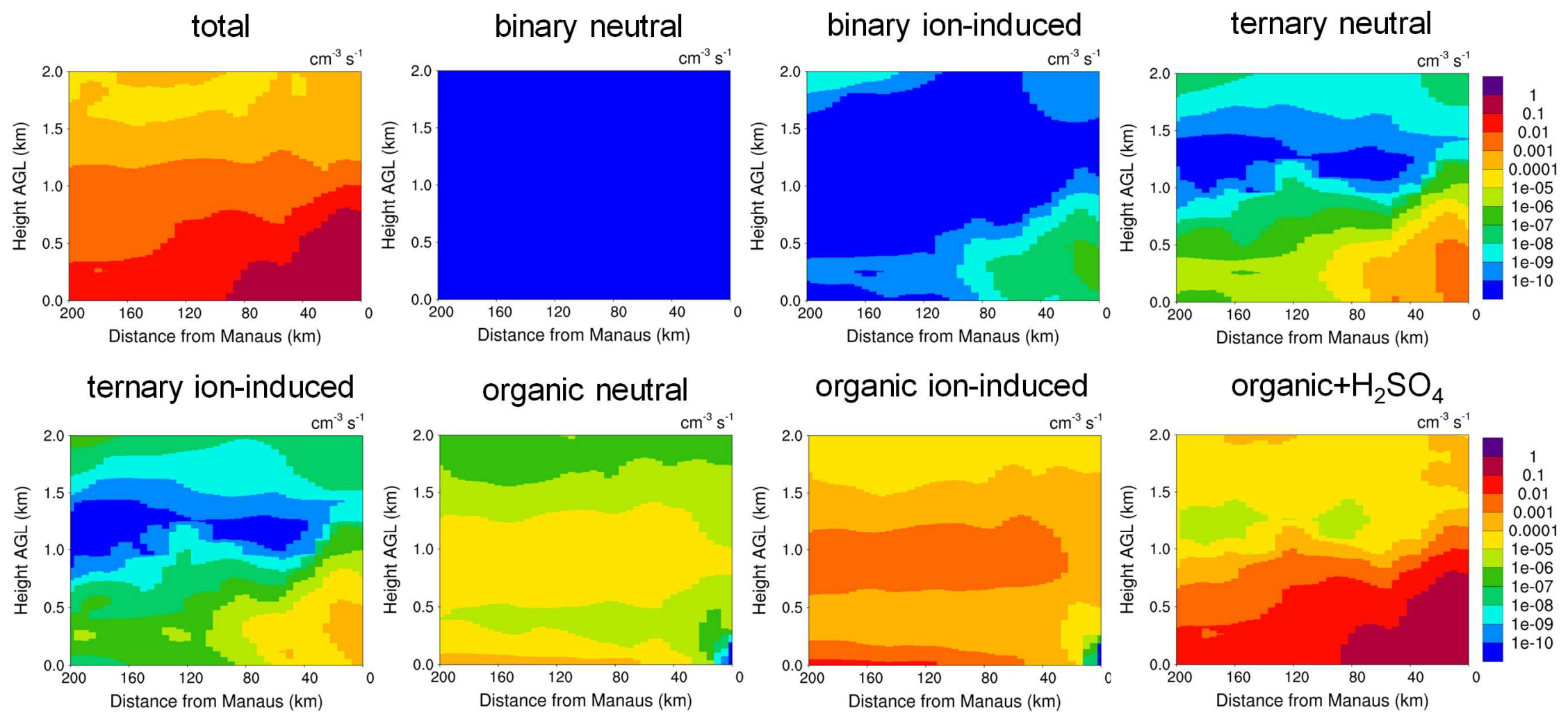

Figure S6. NPF rates from seven pathways and the total NPF study. 

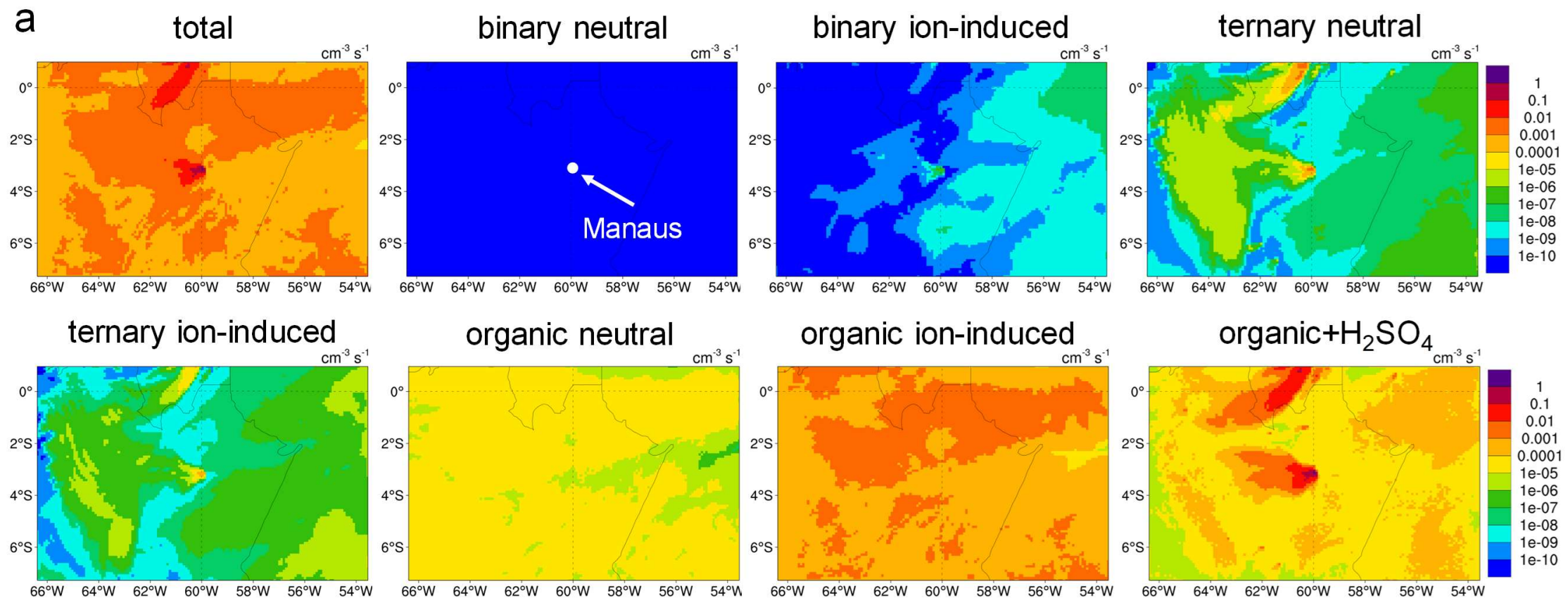

b

Fraction of organic ion-induced
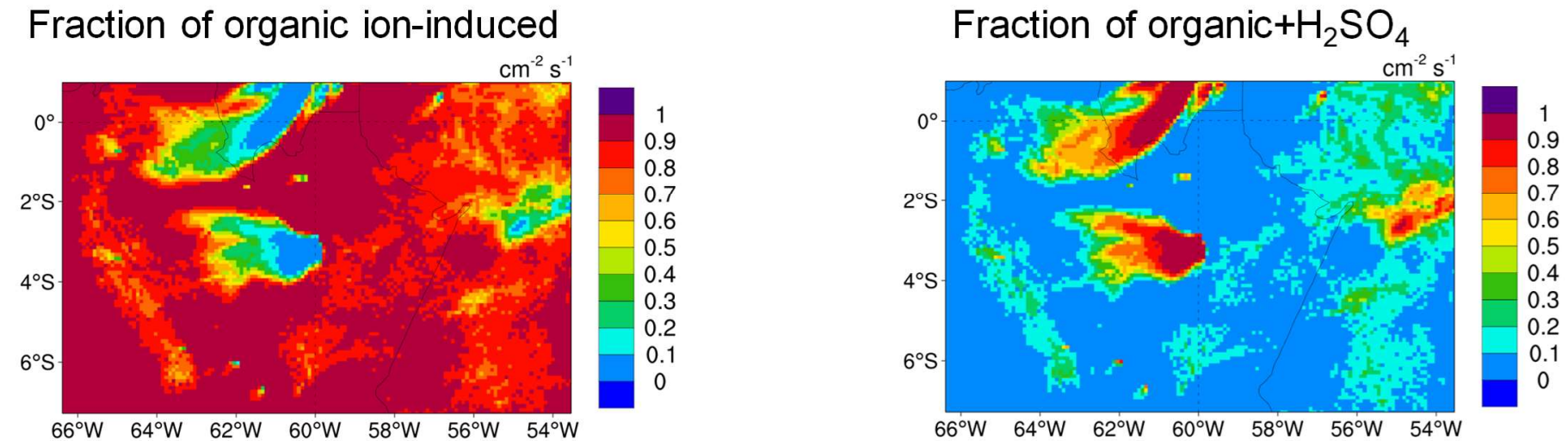

Figure S7. Spatial distribution of the contribution of different NPF pathways. (a) NPF rates from seven pathways and the total NPF rate at a diameter of $1.7 \mathrm{~nm}\left(\mathrm{~J}_{1.7}\right)$ vertically averaged below $2 \mathrm{~km}$, simulated by the base case ("inorg+org_R2D-VBS"). (b) The relative contribution of the pure-organic ion-induced and organic $+\mathrm{H}_{2} \mathrm{SO}_{4}$ pathways to total NPF rate. The results are averaged during the 437 simulation period of this study. 

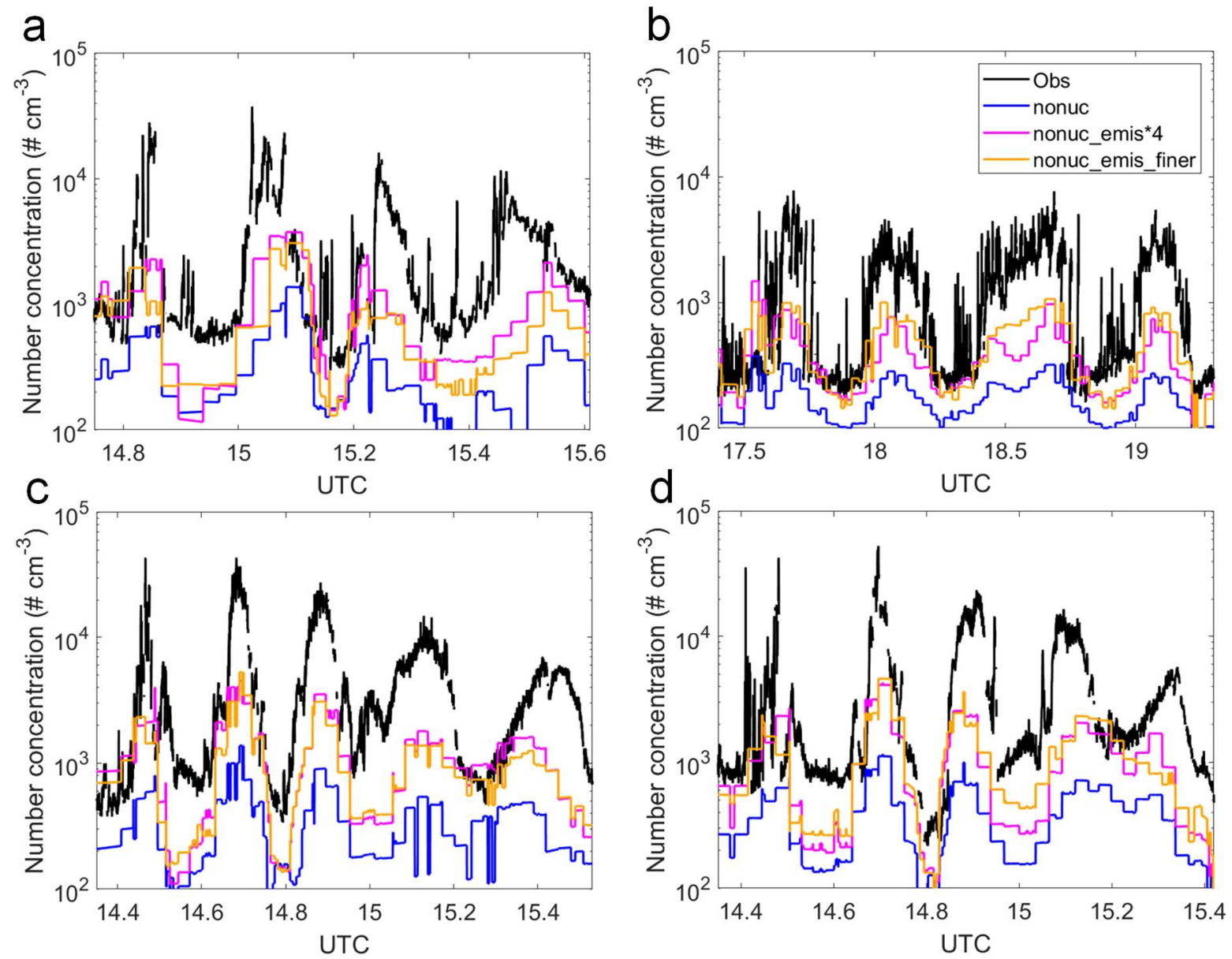

Figure S8. The same as Fig. 2 but for the "nonuc" scenario and two sensitivity scenarios perturbing 440 the emission inventory. The definitions of the model scenarios are summarized in Table S2. 
a
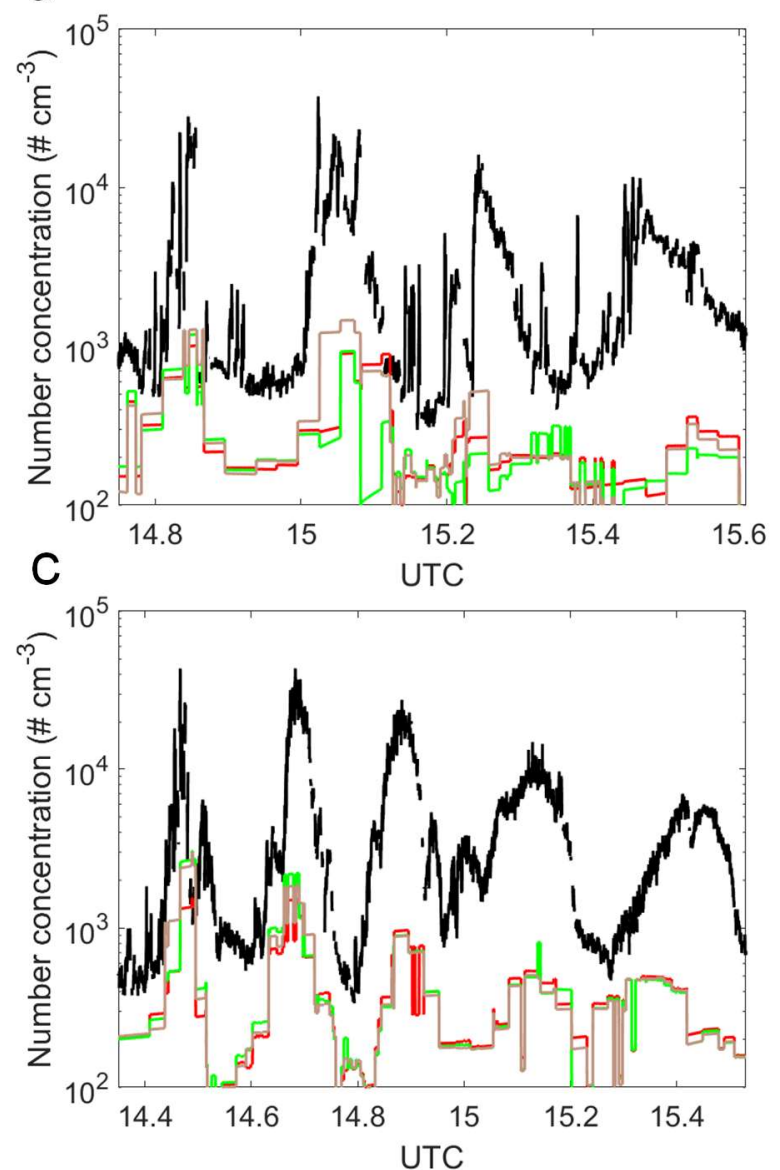

b
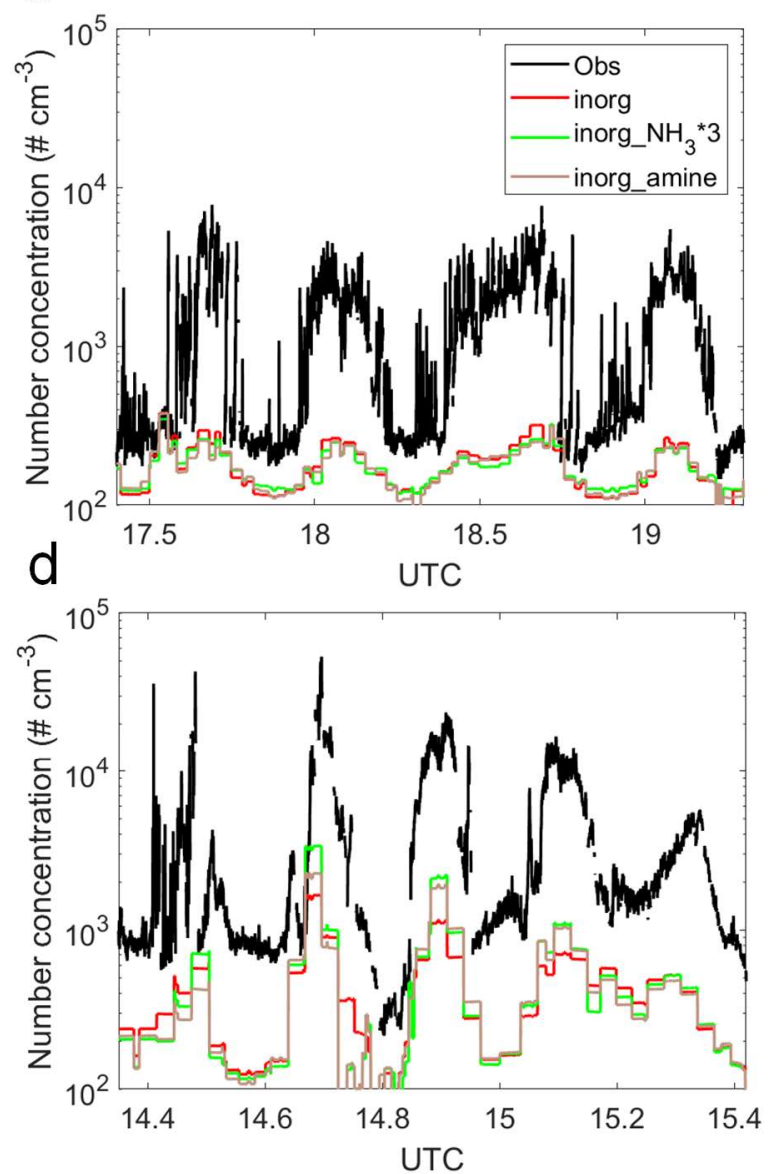

441

442

443 444
Figure S9. The same as Fig. 2 but for the "inorg" scenario, a sensitivity scenario perturbing $\mathrm{NH}_{3}$ concentration, and a sensitivity scenario adding an NPF pathway involving $\mathrm{H}_{2} \mathrm{SO}_{4}$ and amines. The definitions of the model scenarios are summarized in Table S2. 
a
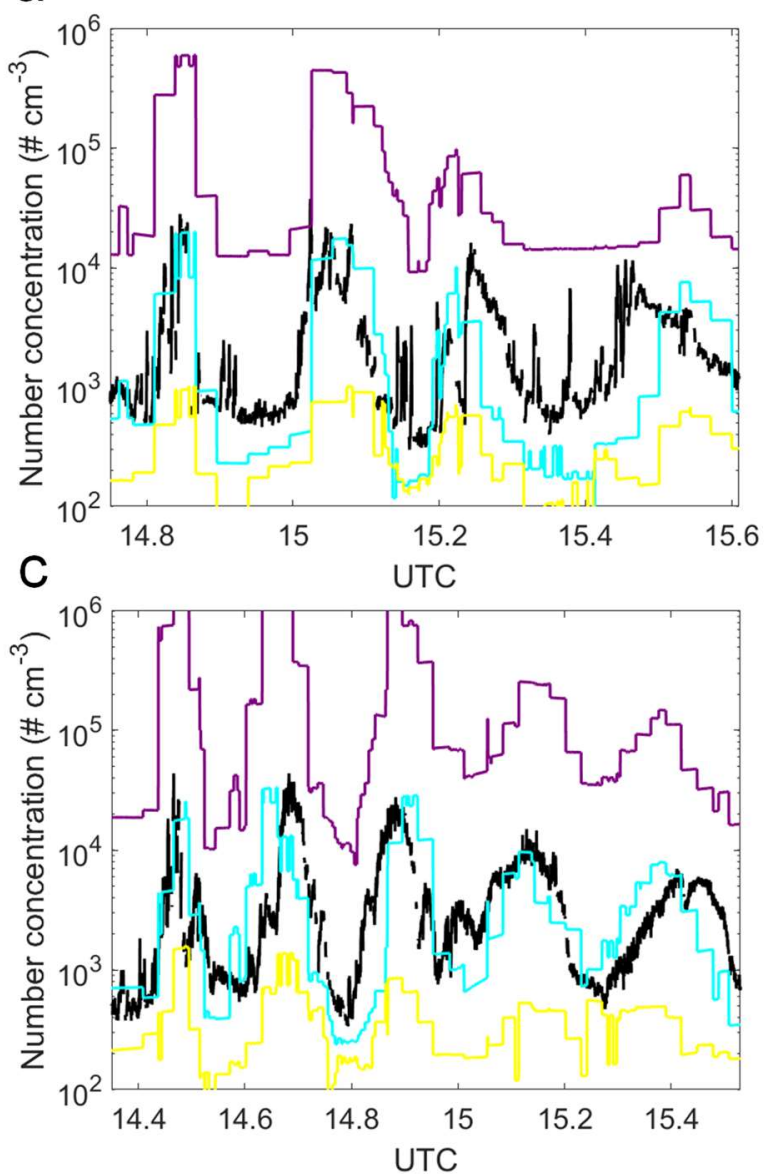

b
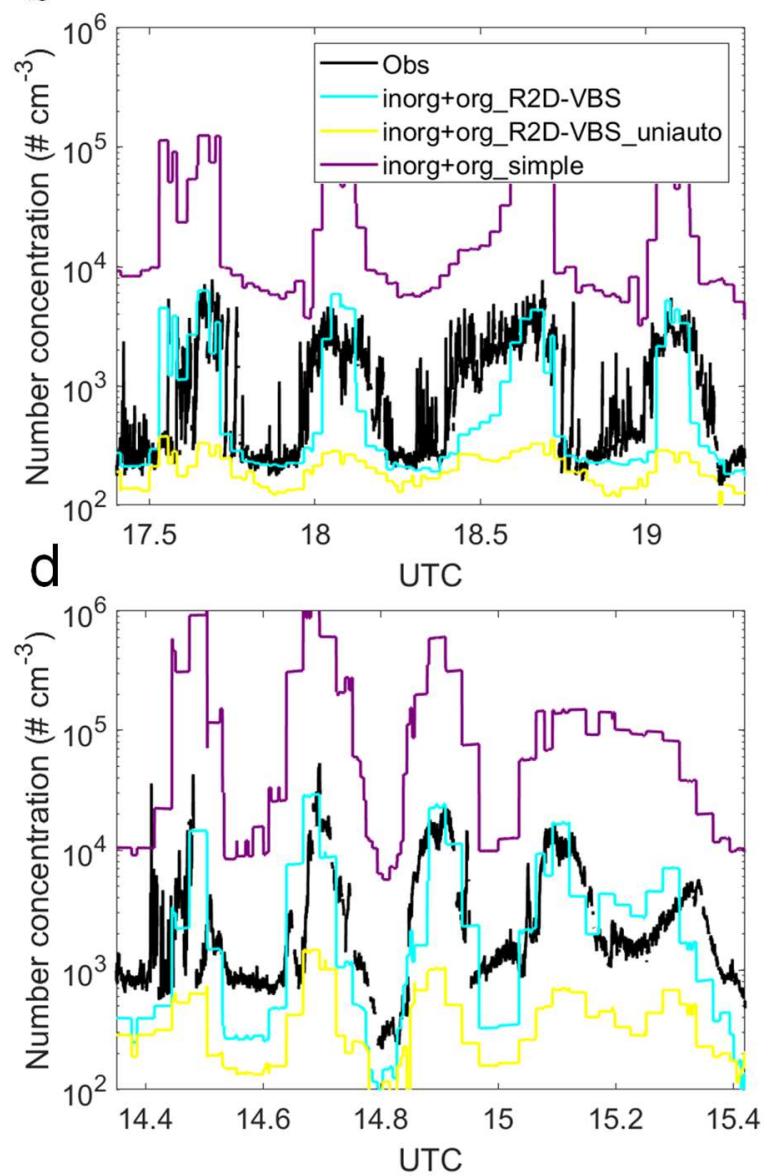

Figure S10. The same as Fig. 2 but for the base case (i.e., inorg+org_R2D-VBS) and two sensitivity scenarios with different treatments of the formation chemistry of the organics that drive NPF. The definitions of the model scenarios are summarized in Table S2. 
a
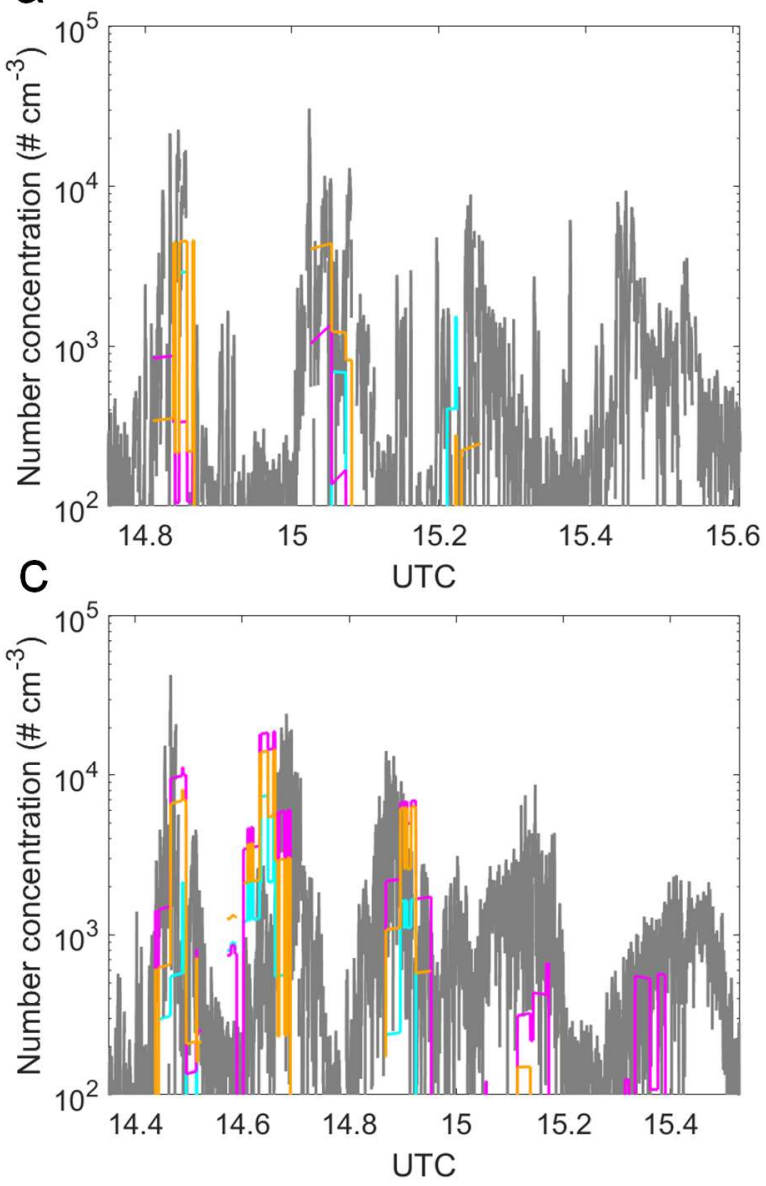

b
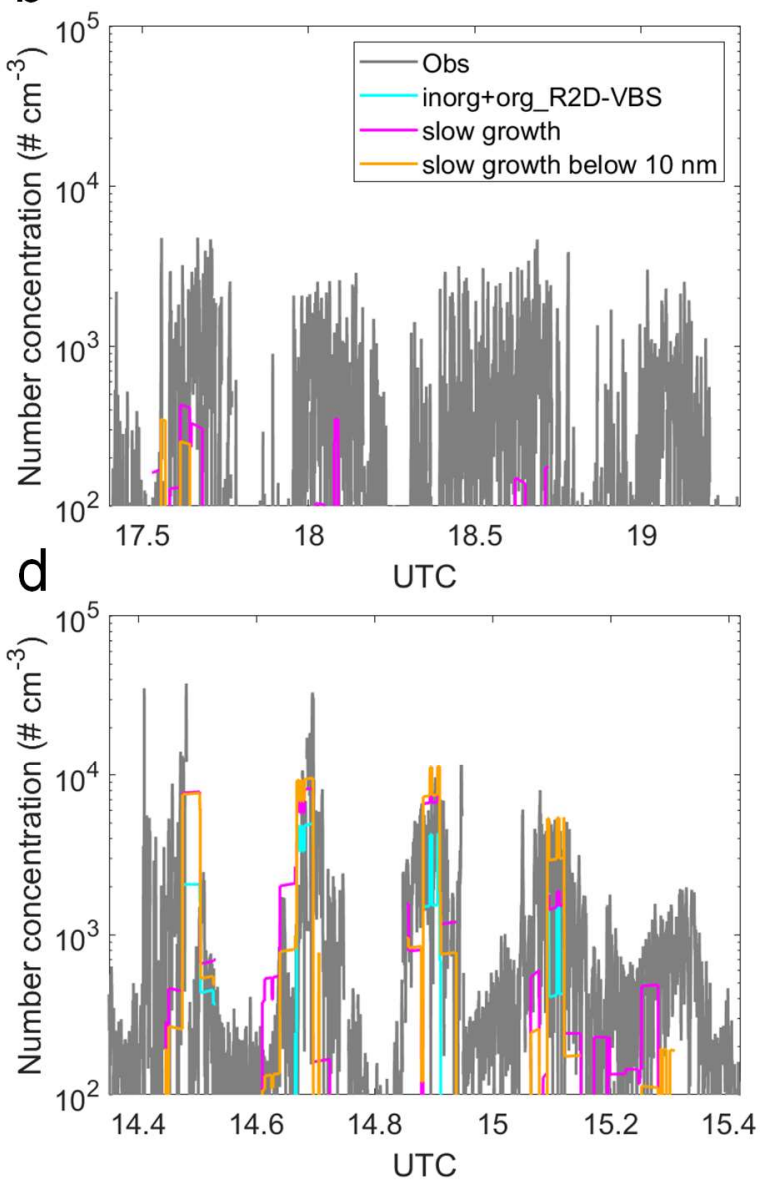

Figure S11. Comparison of simulated particle number concentration in the range of 3-10 nm with G-1 aircraft measurements. (a) March 11, (b) March 12, (c) March 13, and (d) March 14, 2014. The particle number concentrations are normalized to STP. The definitions of the model scenarios are provided in the main text and Table S2.
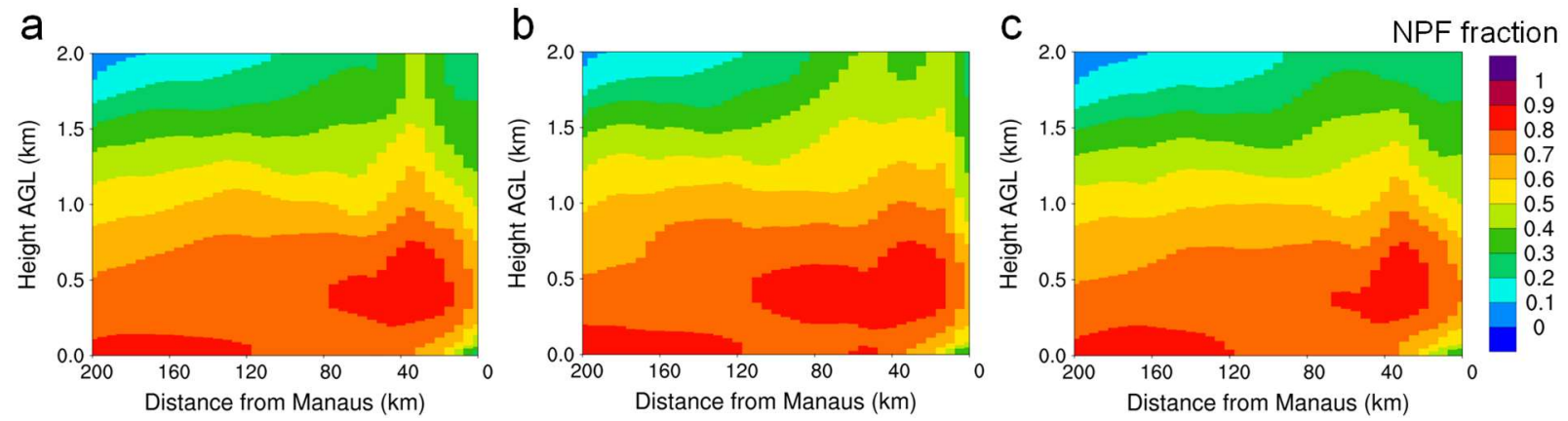

Figure S12. The fractional contribution of NPF within the modeling domain to particle number concentrations on a $2-\mathrm{km}$ high vertical cross section which extends westward from Manaus to $200 \mathrm{~km}$ downwind, simulated by (a) the base case, i.e., "inorg+org_R2D-VBS", (b) the scenario of "slow growth", and (c) the scenario of "slow growth below $10 \mathrm{~nm}$ ". The position of the cross section is marked with a white arrow in Fig. 4d. The results are averaged during the simulation period of this study (March 6-15, 2014). 

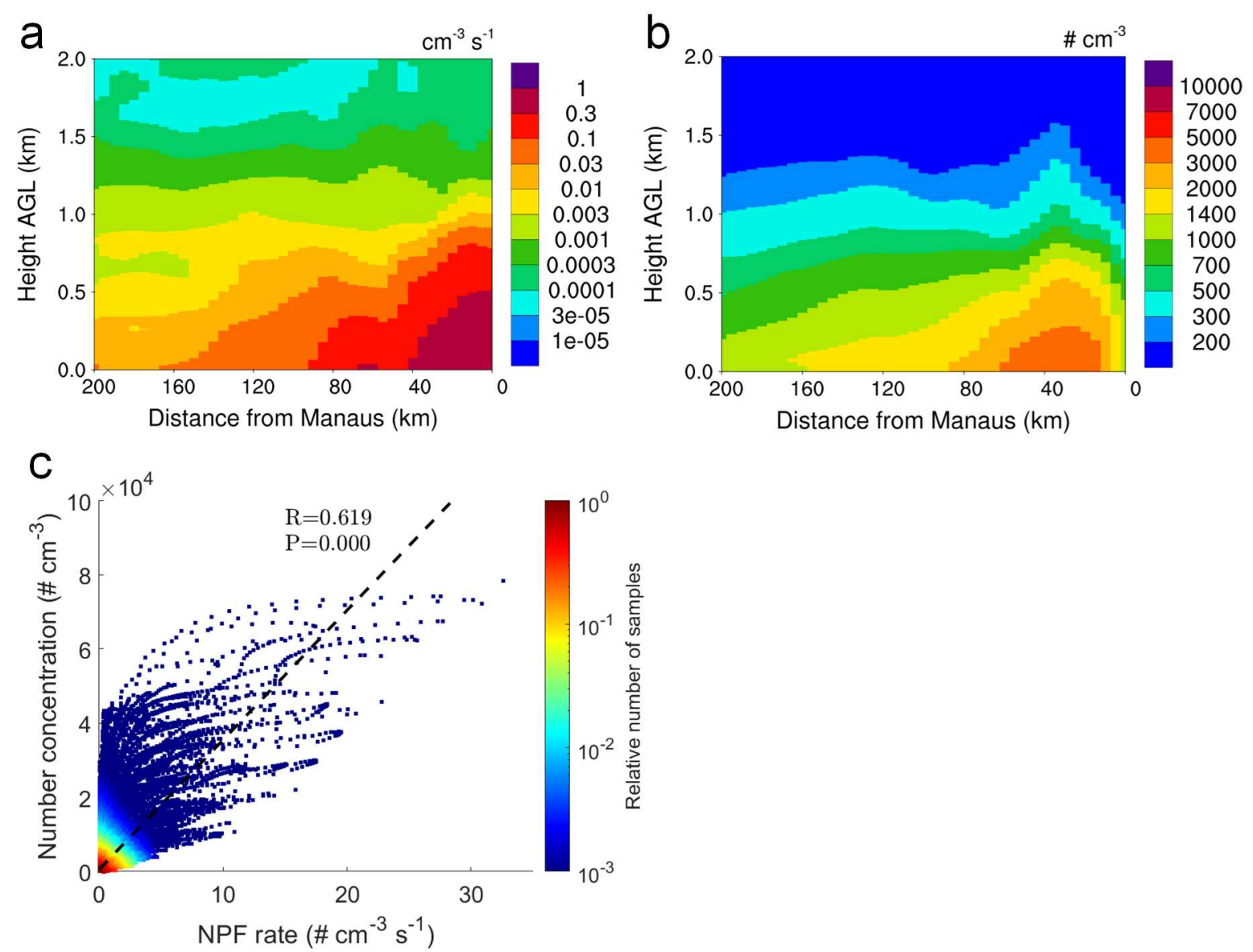

Figure S13. Relationships between NPF rate and increased particle number concentration due to NPF. (a) NPF rate on a 2-km high vertical cross section which extends westward from Manaus to $200 \mathrm{~km}$ downwind. (b) Increased particle number concentration due to NPF on the cross section, which is quantified using the difference between the base case ("inorg+org_R2D-VBS") and the scenario without NPF ("nonuc"). The data in (a) and (b) are averaged during the simulation period of this study (March 6-15, 2014). (c) Scattering plot of hourly average NPF rate vs. increased particle number concentration due to NPF on the cross section during the simulation period. The position of the cross section is marked with a white arrow in Fig. 4d. 
Table S1. Parameters in the NPF model.

\begin{tabular}{|l|l|l|l|}
\hline Parameter & Value & Parameter & Value \\
\hline $\mathrm{p}_{\mathrm{b}, \mathrm{n}}$ & 3.95451 & $\mathrm{p}_{\mathrm{b}, \mathrm{i}}$ & 3.373738 \\
\hline $\mathrm{u}_{\mathrm{b}, \mathrm{n}}$ & 9.702973 & $\mathrm{u}_{\mathrm{b}, \mathrm{i}}$ & -11.48166 \\
\hline $\mathrm{v}_{\mathrm{b}, \mathrm{n}}$ & 12.62259 & $\mathrm{v}_{\mathrm{b}, \mathrm{i}}$ & 25.49469 \\
\hline $\mathrm{w}_{\mathrm{b}, \mathrm{n}}$ & -0.007066146 & $\mathrm{w}_{\mathrm{b}, \mathrm{i}}$ & 0.1810722 \\
\hline $\mathrm{p}_{\mathrm{t}, \mathrm{n}}$ & 2.891024 & $\mathrm{p}_{\mathrm{t}, \mathrm{i}}$ & 3.138719 \\
\hline $\mathrm{u}_{\mathrm{t}, \mathrm{n}}$ & 182.4495 & $\mathrm{u}_{\mathrm{t}, \mathrm{i}}$ & -23.8002 \\
\hline $\mathrm{v}_{\mathrm{t}, \mathrm{n}}$ & 1.203451 & $\mathrm{v}_{\mathrm{t}, \mathrm{i}}$ & 37.03029 \\
\hline $\mathrm{w}_{\mathrm{t}, \mathrm{n}}$ & -4.188065 & $\mathrm{w}_{\mathrm{t}, \mathrm{i}}$ & 0.227413 \\
\hline $\mathrm{p}_{\mathrm{A}, \mathrm{n}}$ & 8.003471 & $\mathrm{p}_{\mathrm{A}, \mathrm{i}}$ & 3.071246 \\
\hline $\mathrm{a}_{\mathrm{n}}$ & $1.5703478 \times 10^{-6}$ & $\mathrm{a}_{\mathrm{i}}$ & 0.0048314 \\
\hline $\mathrm{k}_{\mathrm{SA}-\text { Org }}$ & $3.27 \times 10^{-21}$ & $\mathrm{a}_{1}$ & 0.0400097 \\
\hline $\mathrm{a}_{2}$ & 1.84826 & $\mathrm{a}_{3}$ & 0.00136641 \\
\hline $\mathrm{a}_{4}$ & 1.56588 & $\mathrm{a}_{5}$ & 0.186303 \\
\hline $\mathrm{k}_{\mathrm{SA}-\mathrm{Amine}-1}$ & $2.08 \times 10^{-25}$ & $\mathrm{k}_{\mathrm{SA}-\mathrm{Amine}-2}$ & $1.93 \times 10^{-28}$ \\
\hline
\end{tabular}

471 Note: Full numerical precision is needed. The units of $\left[U L V O C_{O: C>0.4}\right]$ are $10^{7} \mathrm{~cm}^{-3} .\left[\mathrm{H}_{2} \mathrm{SO}_{4}\right]$ has units $10^{6} \mathrm{~cm}^{-3}$ in $472 J_{S A}$ and $J_{S A, N H 3}$, and $\mathrm{cm}^{-3}$ in $J_{S A-o r g}$ and $J_{S A-A m i n e} .\left[N_{3}\right]$ has units $10^{6} \mathrm{~cm}^{-3}$ and $[D M A]$ has units $\mathrm{cm}^{-3}$. The 473 ion and $\left[E L V O C_{O: C>0.4}\right]$ concentrations have units $\mathrm{cm}^{-3}$.

475 Table S2. Summary of model scenarios developed in this study.

\begin{tabular}{|c|c|}
\hline Scenario & Description \\
\hline \multicolumn{2}{|l|}{ Main scenarios } \\
\hline nonuc & A simulation without NPF. \\
\hline inorg & A simulation with only inorganic NPF included. \\
\hline inorg+org_R2D-VBS & $\begin{array}{l}\text { A simulation with both inorganic and organic NPF included, and the } \\
\text { organics that nucleate are simulated employing the updated Radical 2D- } \\
\text { VBS that uses two types of autoxidizable } \mathrm{RO}_{2} \text { with faster and slower } \\
\text { autoxidation rates. This is considered as the base-case scenario and is used } \\
\text { in most analyses of the present study. }\end{array}$ \\
\hline \multicolumn{2}{|l|}{ Sensitivity scenarios } \\
\hline nonuc_emis*4 & $\begin{array}{l}\text { Based on "nonuc", this scenario increases primary particle emissions by a } \\
\text { factor of } 4 .\end{array}$ \\
\hline nonuc_emis_finer & $\begin{array}{l}\text { Based on "nonuc", this scenario reduces the Aitken-mode median diameter } \\
\text { of primary particle emissions from urban sources from } 25 \mathrm{~nm} \text { to } 12 \mathrm{~nm} \text {. }\end{array}$ \\
\hline inorg_ $\mathrm{NH}_{3} * 3$ & $\begin{array}{l}\text { The same as "inorg" except that the } \mathrm{NH}_{3} \text { concentrations across the domain } \\
\text { are increased by a factor of } 3 \text {. }\end{array}$ \\
\hline inorg_amine & $\begin{array}{l}\text { The same as "inorg" except that an NPF pathway involving } \mathrm{H}_{2} \mathrm{SO}_{4} \text { and } \\
\text { amines is incorporated. }\end{array}$ \\
\hline
\end{tabular}




\begin{tabular}{|l|l|}
\hline inorg+org_simple & $\begin{array}{l}\text { The same as “inorg+org_R2D-VBS" except that the organics that nucleate } \\
\text { are assumed to be a fixed fraction of all monoterpene oxidation products. }\end{array}$ \\
\hline inorg+org_R2D-VBS_uniauto & $\begin{array}{l}\text { The same as "inorg+org_R2D-VBS" except that a uniform autoxidation } \\
\text { rate is used for all } \mathrm{RO}_{2} \text { of the same generation. }\end{array}$ \\
\hline
\end{tabular}

477 Table S3. Statistics (mean \pm standard deviation) of major meteorological variables within the 478 modeling domain during the main simulation period in March 2014 and supplementary simulation 479 period in March 2016.

\begin{tabular}{|l|l|l|l|l|}
\hline & \multicolumn{3}{|l|}{ March 6-15, 2014 } & \multicolumn{2}{l|}{ March 6-15, 2016 } \\
\cline { 2 - 5 } & surface & $500 \mathrm{~m}$ & surface & $500 \mathrm{~m}$ \\
\hline Temperature (K) & $298.13 \pm 2.31$ & $296.41 \pm 1.56$ & $298.83 \pm 2.13$ & $297.03 \pm 1.39$ \\
\hline Relative humidity (\%) & $89.55 \pm 11.62$ & $87.49 \pm 9.16$ & $91.35 \pm 10.64$ & $89.63 \pm 8.04$ \\
\hline East-west wind $\left(\mathrm{m} \mathrm{s}^{-1}\right)$ & $-1.11 \pm 1.13$ & $-3.65 \pm 2.70$ & $-0.75 \pm 1.09$ & $-2.68 \pm 2.61$ \\
\hline South-north wind $\left(\mathrm{m} \mathrm{s}^{-1}\right)$ & $-0.35 \pm 1.27$ & $-2.07 \pm 2.91$ & $-0.18 \pm 1.23$ & $-1.36 \pm 2.77$ \\
\hline
\end{tabular}


482

483

484

485

486

487

488

489

490

491

492

493

494

495

496

497

498

499

500

501

502

503

504

505

506

507

508

509

510

511

512

513

514

515

516

517

518

519

520

521

522

523

524

1. Dunne, E. M.; Gordon, H.; Kurten, A.; Almeida, J.; Duplissy, J.; Williamson, C.; Ortega, I. K.; Pringle, K. J.; Adamov, A.; Baltensperger, U.; Barmet, P.; Benduhn, F.; Bianchi, F.; Breitenlechner, M.; Clarke, A.; Curtius, J.; Dommen, J.; Donahue, N. M.; Ehrhart, S.; Flagan, R. C.; Franchin, A.; Guida, R.; Hakala, J.; Hansel, A.; Heinritzi, M.; Jokinen, T.; Kangasluoma, J.; Kirkby, J.; Kulmala, M.; Kupc, A.; Lawler, M. J.; Lehtipalo, K.; Makhmutov, V.; Mann, G.; Mathot, S.; Merikanto, J.; Miettinen, P.; Nenes, A.; Onnela, A.; Rap, A.; Reddington, C. L. S.; Riccobono, F.; Richards, N. A. D.; Rissanen, M. P.; Rondo, L.; Sarnela, N.; Schobesberger, S.; Sengupta, K.; Simon, M.; Sipilaa, M.; Smith, J. N.; Stozkhov, Y.; Tome, A.; Trostl, J.; Wagner, P. E.; Wimmer, D.; Winkler, P. M.; Worsnop, D. R.; Carslaw, K. S., Global atmospheric particle formation from CERN CLOUD measurements. Science 2016, 354, (6316), 1119-1124.

2. Riccobono, F.; Schobesberger, S.; Scott, C. E.; Dommen, J.; Ortega, I. K.; Rondo, L.; Almeida, J.; Amorim, A.; Bianchi, F.; Breitenlechner, M.; David, A.; Downard, A.; Dunne, E. M.; Duplissy, J.; Ehrhart, S.; Flagan, R. C.; Franchin, A.; Hansel, A.; Junninen, H.; Kajos, M.; Keskinen, H.; Kupc, A.; Kurten, A.; Kvashin, A. N.; Laaksonen, A.; Lehtipalo, K.; Makhmutov, V.; Mathot, S.; Nieminen, T.; Onnela, A.; Petaja, T.; Praplan, A. P.; Santos, F. D.; Schallhart, S.; Seinfeld, J. H.; Sipila, M.; Spracklen, D. V.; Stozhkov, Y.; Stratmann, F.; Tome, A.; Tsagkogeorgas, G.; Vaattovaara, P.; Viisanen, Y.; Vrtala, A.; Wagner, P. E.; Weingartner, E.; Wex, H.; Wimmer, D.; Carslaw, K. S.; Curtius, J.; Donahue, N. M.; Kirkby, J.; Kulmala, M.; Worsnop, D. R.; Baltensperger, U., Oxidation products of biogenic emissions contribute to nucleation of atmospheric particles. Science 2014, 344, (6185), 717-721.

3. Kirkby, J.; Duplissy, J.; Sengupta, K.; Frege, C.; Gordon, H.; Williamson, C.; Heinritzi, M.; Simon, M.; Yan, C.; Almeida, J.; Trostl, J.; Nieminen, T.; Ortega, I. K.; Wagner, R.; Adamov, A.; Amorim, A.; Bernhammer, A. K.; Bianchi, F.; Breitenlechner, M.; Brilke, S.; Chen, X. M.; Craven, J.; Dias, A.; Ehrhart, S.; Flagan, R. C.; Franchin, A.; Fuchs, C.; Guida, R.; Hakala, J.; Hoyle, C. R.; Jokinen, T.; Junninen, H.; Kangasluoma, J.; Kim, J.; Krapf, M.; Kurten, A.; Laaksonen, A.; Lehtipalo, K.; Makhmutov, V.; Mathot, S.; Molteni, U.; Onnela, A.; Perakyla, O.; Piel, F.; Petaja, T.; Praplan, A. P.; Pringle, K.; Rap, A.; Richards, N. A. D.; Riipinen, I.; Rissanen, M. P.; Rondo, L.; Sarnela, N.; Schobesberger, S.; Scott, C. E.; Seinfeld, J. H.; Sipila, M.; Steiner, G.; Stozhkov, Y.; Stratmann, F.; Tome, A.; Virtanen, A.; Vogel, A. L.; Wagner, A. C.; Wagner, P. E.; Weingartner, E.; Wimmer, D.; Winkler, P. M.; Ye, P. L.; Zhang, X.; Hansel, A.; Dommen, J.; Donahue, N. M.; Worsnop, D. R.; Baltensperger, U.; Kulmala, M.; Carslaw, K. S.; Curtius, J., Ioninduced nucleation of pure biogenic particles. Nature 2016, 533, (7604), 521-526.

4. Gordon, H.; Kirkby, J.; Baltensperger, U.; Bianchi, F.; Breitenlechner, M.; Curtius, J.; Dias, A.; Dommen, J.; Donahue, N. M.; Dunne, E. M.; Duplissy, J.; Ehrhart, S.; Flagan, R. C.; Frege, C.; Fuchs, C.; Hansel, A.; Hoyle, C. R.; Kulmala, M.; Kurten, A.; Lehtipalo, K.; Makhmutov, V.; Molteni, U.; Rissanen, M. P.; Stozkhov, Y.; Trostl, J.; Tsagkogeorgas, G.; Wagner, R.; Williamson, C.; Wimmer, D.; Winkler, P. M.; Yan, C.; Carslaw, K. S., Causes and importance of new particle formation in the present-day and preindustrial atmospheres. J Geophys Res-Atmos 2017, 122, (16), 8739-8760.

5. Zhao, B.; Shrivastava, M.; Donahue, N. M.; Gordon, H.; Schervish, M.; Shilling, J. E.; Zaveri, R. A.; Wang, J.; Andreae, M. O.; Zhao, C.; Gaudet, B.; Liu, Y.; Fan, J. W.; Fast, J. D., High concentration of ultrafine particles in the Amazon free troposphere produced by organic new particle formation. P Natl Acad Sci USA 2020, 117, (41), 25344-25351. 
6. Jokinen, T.; Berndt, T.; Makkonen, R.; Kerminen, V. M.; Junninen, H.; Paasonen, P.; Stratmann, F.; Herrmann, H.; Guenther, A. B.; Worsnop, D. R.; Kulmala, M.; Ehn, M.; Sipila, M., Production of extremely low volatile organic compounds from biogenic emissions: Measured yields and atmospheric implications. P Natl Acad Sci USA 2015, 112, (23), 7123-7128.

7. Li, X. X.; Chee, S.; Hao, J. M.; Abbatt, J. P. D.; Jiang, J. K.; Smith, J. N., Relative humidity effect on the formation of highly oxidized molecules and new particles during monoterpene oxidation. Atmos Chem Phys 2019, 19, (3), 1555-1570.

8. Zaveri, R. A.; Easter, R. C.; Fast, J. D.; Peters, L. K., Model for simulating aerosol interactions and chemistry (MOSAIC). J Geophys Res-Atmos 2008, 113, (D13), D13204.

9. Hanson, D. R., Mass accommodation of $\mathrm{H} 2 \mathrm{SO} 4$ and $\mathrm{CH} 3 \mathrm{SO} 3 \mathrm{H}$ on water-sulfuric acid solutions from 6\% to 97\% RH. J Phys Chem A 2005, 109, (31), 6919-6927.

10. Fahey, K. M.; Pandis, S. N., Optimizing model performance: variable size resolution in cloud chemistry modeling. Atmos Environ 2001, 35, (26), 4471-4478.

11. Guenther, A. B.; Jiang, X.; Heald, C. L.; Sakulyanontvittaya, T.; Duhl, T.; Emmons, L. K.; Wang, X., The Model of Emissions of Gases and Aerosols from Nature version 2.1 (MEGAN2.1): an extended and updated framework for modeling biogenic emissions. Geosci Model Dev 2012, 5, (6), 1471-1492.

12. Zhao, C.; Huang, M. Y.; Fast, J. D.; Berg, L. K.; Qian, Y.; Guenther, A.; Gu, D. S.; Shrivastava, M.; Liu, Y.; Walters, S.; Pfister, G.; Jin, J. M.; Shilling, J. E.; Warneke, C., Sensitivity of biogenic volatile organic compounds to land surface parameterizations and vegetation distributions in California. Geosci Model Dev 2016, 9, (5), 1959-1976.

13. Shrivastava, M.; Andreae, M. O.; Artaxo, P.; Barbosa, H. M. J.; Berg, L. K.; Brito, J.; Ching, J.; Easter, R. C.; Fan, J. W.; Fast, J. D.; Feng, Z.; Fuentes, J. D.; Glasius, M.; Goldstein, A. H.; Alves, E. G.; Gomes, H.; Gu, D.; Guenther, A.; Jathar, S. H.; Kim, S.; Liu, Y.; Lou, S. J.; Martin, S. T.; McNeill, V. F.; Medeiros, A.; de Sa, S. S.; Shilling, J. E.; Springston, S. R.; Souza, R. A. F.; Thornton, J. A.; Isaacman-VanWertz, G.; Yee, L. D.; Ynoue, R.; Zaveri, R. A.; Zelenyuk, A.; Zhao, C., Urban pollution greatly enhances formation of natural aerosols over the Amazon rainforest. Nat Commun 2019, 10, 1046.

14. Martin, S. T.; Artaxo, P.; Machado, L.; Manzi, A. O.; Souza, R. A. F.; Schumacher, C.; Wang, J.; Biscaro, T.; Brito, J.; Calheiros, A.; Jardine, K.; Medeiros, A.; Portela, B.; de Sa, S. S.; Adachi, K.; Aiken, A. C.; Albrecht, R.; Alexander, L.; Andreae, M. O.; Barbosa, M. J.; Buseck, P.; Chand, D.; Comstock, J. M.; Day, D. A.; Dubey, M.; Fan, J.; Fast, J.; Fisch, G.; Fortner, E.; Giangrande, S.; Gilles, M.; Goldststein, A. H.; Guenther, A.; Hubbe, J.; Jensen, M.; Jimenez, J. L.; Keutsch, F. N.; Kim, S.; Kuang, C.; Laskskin, A.; McKinney, K.; Mei, F.; Miller, M.; Nascimento, R.; Pauliquevis, T.; Pekour, M.; Peres, J.; Petaja, T.; Pohlker, C.; Poschl, U.; Rizzo, L.; Schmid, B.; Shilling, J. E.; Dias, M. A. S.; Smith, J. N.; Tomlmlinson, J. M.; Tota, J.; Wendisch, M., The Green Ocean Amazon experiment (GoAmazon2014/5) observes pollution affecting gases, aerosols, clouds, and rainfall over the rain forest. B Am Meteorol Soc 2017, 98, (5), 981-997.

15. Wang, J.; Krejci, R.; Giangrandel, S.; Kuang, C.; Barbosa, H. M. J.; Brito, J.; Carbone, S.; Chi, X. G.; Comstock, J.; Ditas, F.; Lavric, J.; Manninen, H. E.; Mei, F.; Moran-Zuloaga, D.; Pohlker, C.; Pohlker, M. L.; Saturno, J.; Schmid, B.; Souza, R. A. F.; Springston, S. R.; Tomlinson, J. M.; Toto, T.; Walter, D.; Wimmer, D.; Smith, J. N.; Kulmala, M.; Machado, L. A. T.; Artaxo, P.; Andreae, M. O.; Petaja, T.; Martin, S. T., Amazon boundary layer aerosol concentration sustained by vertical transport during rainfall. Nature 2016, 539, (7629), 416-419.

16. Shilling, J. E.; Pekour, M. S.; Fortner, E. C.; Artaxo, P.; de Sa, S.; Hubbe, J. M.; Longo, K. M.; Machado, L. A. T.; Martin, S. T.; Springston, S. R.; Tomlinson, J.; Wang, J., Aircraft 
observations of the chemical composition and aging of aerosol in the Manaus urban plume during GoAmazon 2014/5. Atmos Chem Phys 2018, 18, (14), 10773-10797. for rapid measurement of sub-micrometer aerosol size distribution, Part I: Design and model evaluation. J Aerosol Sci 2017, 108, 44-55.

18. Kim, S. Observations and Modeling of the Green Ocean Amazon 2014/15: hydroxyl radical $(\mathrm{OH})$ chemical ionization mass spectrometer (CIMS) field campaign report, available at https://www.arm.gov/publications/programdocs/doe-sc-arm-15-061.pdf; University of California, Irvine: 2016.

19. Trebs, I.; Lara, L. L.; Zeri, L. M. M.; Gatti, L. V.; Artaxo, P.; Dlugi, R.; Slanina, J.; Andreae, M. O.; Meixner, F. X., Dry and wet deposition of inorganic nitrogen compounds to a tropical pasture site (Rondonia, Brazil). Atmos Chem Phys 2006, 6, 447-469.

20. Zaveri, R. A.; Easter, R. C.; Shilling, J. E.; Seinfeld, J. H., Modeling kinetic partitioning of secondary organic aerosol and size distribution dynamics: representing effects of volatility, phase state, and particle-phase reaction. Atmos Chem Phys 2014, 14, (10), 5153-5181.

21. Zaveri, R. A.; Shilling, J. E.; Zelenyuk, A.; Liu, J. M.; Bell, D. M.; D'Ambro, E. L.; Gaston, C.; Thornton, J. A.; Laskin, A.; Lin, P.; Wilson, J.; Easter, R. C.; Wang, J.; Bertram, A. K.; Martin, S. T.; Seinfeld, J. H.; Worsnop, D. R., Growth Kinetics and Size Distribution Dynamics of Viscous Secondary Organic Aerosol. Environ Sci Technol 2018, 52, (3), 1191-1199.

22. Zaveri, R. A.; Wang, J.; Fan, J.; Zhang, Y.; Shilling, J. E.; Zelenyuk, A.; Mei, F.; Newsom, R.; Pekour, M.; Tomlinson, J.; Comstock, J. M.; Shrivastava, M.; Fortner, E.; Machado, L. A. T.; Artaxo, P.; Martin, S. T., Rapid growth of air pollution nanoparticles impacts clouds and precipitation in the Amazon rainforest. under review 2020.

23. Kerminen, V. M.; Chen, X. M.; Vakkari, V.; Petaja, T.; Kulmala, M.; Bianchi, F., Atmospheric new particle formation and growth: review of field observations. Environ Res Lett 2018, 13, (10), 103003.

24. Lee, S. H.; Gordon, H.; Yu, H.; Lehtipalo, K.; Haley, R.; Li, Y. X.; Zhang, R. Y., New Particle Formation in the Atmosphere: From Molecular Clusters to Global Climate. J Geophys Res-Atmos 2019, 124, (13), 7098-7146.

25. Matsui, H.; Koike, M.; Kondo, Y.; Takegawa, N.; Wiedensohler, A.; Fast, J. D.; Zaveri, R. A., Impact of new particle formation on the concentrations of aerosols and cloud condensation nuclei around Beijing. J Geophys Res-Atmos 2011, 116, D19208.

26. Cui, Y. Y.; Hodzic, A.; Smith, J. N.; Ortega, J.; Brioude, J.; Matsui, H.; Levin, E. J. T.; Turnipseed, A.; Winkler, P.; de Foy, B., Modeling ultrafine particle growth at a pine forest site influenced by anthropogenic pollution during BEACHON-RoMBAS 2011. Atmos Chem Phys 2014, 14, (20), 11011-11029.

27. Lupascu, A.; Easter, R.; Zaveri, R.; Shrivastava, M.; Pekour, M.; Tomlinson, J.; Yang, Q.; Matsui, H.; Hodzic, A.; Zhang, Q.; Fast, J. D., Modeling particle nucleation and growth over northern California during the 2010 CARES campaign. Atmos Chem Phys 2015, 15, (21), 1228312313.

28. Luo, G.; Yu, F., Simulation of particle formation and number concentration over the Eastern United States with the WRF-Chem plus APM model. Atmos Chem Phys 2011, 11, (22), 1152111533.

29. Chen, X. S.; Wang, Z. F.; Li, J.; Yang, W. Y.; Chen, H. S.; Wang, Z.; Hao, J. Q.; Ge, B. Z.; Wang, D. W.; Huang, H. L., Simulation on different response characteristics of aerosol particle 
number concentration and mass concentration to emission changes over mainland China. Sci Total Environ 2018, 643, 692-703.

30. Keskinen, J.; Ronkko, T., Can Real-World Diesel Exhaust Particle Size Distribution be Reproduced in the Laboratory? A Critical Review. J Air Waste Manage 2010, 60, (10), 1245-1255. 31. Shi, J. P.; Harrison, R. M.; Brear, F., Particle size distribution from a modern heavy duty diesel engine. Sci Total Environ 1999, 235, (1-3), 305-317.

32. Weimer, S.; Mohr, C.; Richter, R.; Keller, J.; Mohr, M.; Prevot, A. S. H.; Baltensperger, U., Mobile measurements of aerosol number and volume size distributions in an Alpine valley: Influence of traffic versus wood burning. Atmos Environ 2009, 43, (3), 624-630.

33. Yao, L.; Garmash, O.; Bianchi, F.; Zheng, J.; Yan, C.; Kontkanen, J.; Junninen, H.; Mazon, S. B.; Ehn, M.; Paasonen, P.; Sipila, M.; Wang, M. Y.; Wang, X. K.; Xiao, S.; Chen, H. F.; Lu, Y. Q.; Zhang, B. W.; Wang, D. F.; Fu, Q. Y.; Geng, F. H.; Li, L.; Wang, H. L.; Qiao, L. P.; Yang, X.; Chen, J. M.; Kerminen, V. M.; Petaja, T.; Worsnop, D. R.; Kulmala, M.; Wang, L., Atmospheric new particle formation from sulfuric acid and amines in a Chinese megacity. Science 2018, 361, (6399), 278-+.

34. Zhao, J.; Smith, J. N.; Eisele, F. L.; Chen, M.; Kuang, C.; McMurry, P. H., Observation of neutral sulfuric acid-amine containing clusters in laboratory and ambient measurements. Atmos Chem Phys 2011, 11, (21), 10823-10836.

35. Almeida, J.; Schobesberger, S.; Kurten, A.; Ortega, I. K.; Kupiainen-Maatta, O.; Praplan, A. P.; Adamov, A.; Amorim, A.; Bianchi, F.; Breitenlechner, M.; David, A.; Dommen, J.; Donahue, N. M.; Downard, A.; Dunne, E.; Duplissy, J.; Ehrhart, S.; Flagan, R. C.; Franchin, A.; Guida, R.; Hakala, J.; Hansel, A.; Heinritzi, M.; Henschel, H.; Jokinen, T.; Junninen, H.; Kajos, M.; Kangasluoma, J.; Keskinen, H.; Kupc, A.; Kurten, T.; Kvashin, A. N.; Laaksonen, A.; Lehtipalo, K.; Leiminger, M.; Leppa, J.; Loukonen, V.; Makhmutov, V.; Mathot, S.; McGrath, M. J.; Nieminen, T.; Olenius, T.; Onnela, A.; Petaja, T.; Riccobono, F.; Riipinen, I.; Rissanen, M.; Rondo, L.; Ruuskanen, T.; Santos, F. D.; Sarnela, N.; Schallhart, S.; Schnitzhofer, R.; Seinfeld, J. H.; Simon, M.; Sipila, M.; Stozhkov, Y.; Stratmann, F.; Tome, A.; Trostl, J.; Tsagkogeorgas, G.; Vaattovaara, P.; Viisanen, Y.; Virtanen, A.; Vrtala, A.; Wagner, P. E.; Weingartner, E.; Wex, H.; Williamson, C.; Wimmer, D.; Ye, P. L.; Yli-Juuti, T.; Carslaw, K. S.; Kulmala, M.; Curtius, J.; Baltensperger, U.; Worsnop, D. R.; Vehkamaki, H.; Kirkby, J., Molecular understanding of sulphuric acid-amine particle nucleation in the atmosphere. Nature 2013, 502, (7471), 359-363.

36. Bergman, T.; Laaksonen, A.; Korhonen, H.; Malila, J.; Dunne, E. M.; Mielonen, T.; Lehtinen, K. E. J.; Kuhn, T.; Arola, A.; Kokkola, H., Geographical and diurnal features of amine-enhanced boundary layer nucleation. J Geophys Res-Atmos 2015, 120, (18), 9606-9624.

37. Yu, F.; Luo, G., Modeling of gaseous methylamines in the global atmosphere: impacts of oxidation and aerosol uptake. Atmos Chem Phys 2014, 14, (22), 12455-12464.

38. Chen, X. S.; Yang, W. Y.; Wang, Z. F.; Li, J.; Hu, M.; An, J. L.; Wu, Q. Z.; Wang, Z.; Chen, H. S.; Wei, Y.; Du, H. Y.; Wang, D. W., Improving new particle formation simulation by coupling a volatility-basis set (VBS) organic aerosol module in NAQPMS plus APM. Atmos Environ 2019, 204, 1-11.

39. Scott, C. E.; Rap, A.; Spracklen, D. V.; Forster, P. M.; Carslaw, K. S.; Mann, G. W.; Pringle, K. J.; Kivekas, N.; Kulmala, M.; Lihavainen, H.; Tunved, P., The direct and indirect radiative effects of biogenic secondary organic aerosol. Atmos Chem Phys 2014, 14, (1), 447-470.

40. Gordon, H.; Sengupta, K.; Rap, A.; Duplissy, J.; Frege, C.; Williamson, C.; Heinritzi, M.; Simon, M.; Yan, C.; Almeida, J.; Trostl, J.; Nieminen, T.; Ortega, I. K.; Wagner, R.; Dunne, E. M.; Adamov, A.; Amorim, A.; Bernhammer, A. K.; Bianchi, F.; Breitenlechner, M.; Brilke, S.; 
Chen, X. M.; Craven, J. S.; Dias, A.; Ehrhart, S.; Fischer, L.; Flagan, R. C.; Franchin, A.; Fuchs, C.; Guida, R.; Hakala, J.; Hoyle, C. R.; Jokinen, T.; Junninen, H.; Kangasluoma, J.; Kim, J.; Kirkby, J.; Krapf, M.; Kurten, A.; Laaksonen, A.; Lehtipalo, K.; Makhmutov, V.; Mathot, S.; Molteni, U.; Monks, S. A.; Onnela, A.; Perakyla, O.; Piel, F.; Petaja, T.; Praplanh, A. P.; Pringle, K. J.; Richards, N. A. D.; Rissanen, M. P.; Rondo, L.; Sarnela, N.; Schobesberger, S.; Scott, C. E.; Seinfeldo, J. H.; Sharma, S.; Sipila, M.; Steiner, G.; Stozhkov, Y.; Stratmann, F.; Tome, A.; Virtanen, A.; Vogel, Zhang, X.; Hansel, A.; Dommen, J.; Donahue, N. M.; Worsnop, D. R.; Baltensperger, U.; Kulmala, M.; Curtius, J.; Carslaw, K. S., Reduced anthropogenic aerosol radiative forcing caused by biogenic new particle formation. P Natl Acad Sci USA 2016, 113, (43), 12053-12058.

41. Inomata, S.; Sato, K.; Sakamoto, Y.; Hirokawa, J., Direct observation of new particle formation during ozonolysis of isoprene and ethene competing against the growth of preexisting particles. Atmos Environ 2017, 170, 149-155.

42. Kiendler-Scharr, A.; Wildt, J.; Dal Maso, M.; Hohaus, T.; Kleist, E.; Mentel, T. F.; Tillmann, R.; Uerlings, R.; Schurr, U.; Wahner, A., New particle formation in forests inhibited by isoprene emissions. Nature 2009, 461, (7262), 381-384.

43. Lee, S. H.; Uin, J.; Guenther, A. B.; de Gouw, J. A.; Yu, F. Q.; Nadykto, A. B.; Herb, J.; Ng, N. L.; Koss, A.; Brune, W. H.; Baumann, K.; Kanawade, V. P.; Keutsch, F. N.; Nenes, A.; Olsen, K.; Goldstein, A.; Ouyang, Q., Isoprene suppression of new particle formation: Potential mechanisms and implications. J Geophys Res-Atmos 2016, 121, (24), 14621-14635.

44. Heinritzi, M.; Dada, L.; Simon, M.; Stolzenburg, D.; Wagner, A. C., Molecular understanding of the suppression of new-particle formation by isoprene. Atmos Chem Phys 2020, 20, 1180911821.

45. Bonn, B.; Moortgat, G. K., Sesquiterpene ozonolysis: Origin of atmospheric new particle formation from biogenic hydrocarbons. Geophys Res Lett 2003, 30, (11), 1585.

46. Molteni, U.; Bianchi, F.; Klein, F.; El Haddad, I.; Frege, C.; Rossi, M. J.; Dommen, J.; Baltensperger, U., Formation of highly oxygenated organic molecules from aromatic compounds. Atmos Chem Phys 2018, 18, (3), 1909-1921.

47. Wang, M. Y.; Chen, D. X.; Xiao, M.; Ye, Q.; Stolzenburg, D.; Hofbauer, V.; Ye, P. L.; Vogel, A. L.; Mauldin, R. L.; Amorim, A.; Baccarini, A.; Baumgartner, B.; Brilke, S.; Dada, L.; Dias, A.; Duplissy, J.; Finkenzeller, H.; Garmash, O.; He, X. C.; Hoyle, C. R.; Kim, C.; Kvashnin, A.; Lehtipalo, K.; Fischer, L.; Molteni, U.; Petaja, T.; Pospisilova, V.; Quelever, L. L. J.; Rissanen, M.; Simon, M.; Tauber, C.; Tome, A.; Wagner, A. C.; Weitz, L.; Volkamer, R.; Winkler, P. M.; Kirkby, J.; Worsnop, D. R.; Kulmala, M.; Baltensperger, U.; Dommen, J.; El Haddad, I.; Donahue, N. M., Photo-oxidation of Aromatic Hydrocarbons Produces Low-Volatility Organic Compounds. Environ Sci Technol 2020, 54, (13), 7911-7921.

48. Pospisilova, V.; Lopez-Hilfiker, F. D.; Bell, D. M.; El Haddad, I.; Mohr, C.; Huang, W.; Heikkinen, L.; Xiao, M.; Dommen, J.; Prevot, A. S. H.; Baltensperger, U.; Slowik, J. G., On the fate of oxygenated organic molecules in atmospheric aerosol particles. Sci $A d v$ 2020, 6, (11), eaax8922.

49. Bianchi, F.; Kurten, T.; Riva, M.; Mohr, C.; Rissanen, M. P.; Roldin, P.; Berndt, T.; Crounse, J. D.; Wennberg, P. O.; Mentel, T. F.; Wildt, J.; Junninen, H.; Jokinen, T.; Kulmala, M.; Worsnop, D. R.; Thornton, J. A.; Donahue, N.; Kjaergaard, H. G.; Ehn, M., Highly oxygenated organic molecules (HOM) from gas-phase autoxidation involving peroxy radicals: a key contributor to atmospheric aerosol. Chem Rev 2019, 119, (6), 3472-3509. 
50. Zawadowicz, M. A.; Lee, B.; Shrivastava, M.; Zelenyuk, A.; Zaveri, R. A.; Flynn, C.; Thornton, J. A.; Shilling, J. E., Photolysis Controls Atmospheric Budgets of Biogenic Secondary Organic Aerosol. Environ Sci Technol 2020, 54, (7), 3861-3870. 51. Kurten, A.; Jokinen, T.; Simon, M.; Sipila, M.; Sarnela, N.; Junninen, H.; Adamov, A.; Almeida, J.; Amorim, A.; Bianchi, F.; Breitenlechner, M.; Dommen, J.; Donahue, N. M.; Duplissy, J.; Ehrhart, S.; Flagan, R. C.; Franchin, A.; Hakala, J.; Hansel, A.; Heinritzi, M.; Hutterli, M.; Kangasluoma, J.; Kirkby, J.; Laaksonen, A.; Lehtipalo, K.; Leiminger, M.; Makhmutov, V.; Mathot, S.; Onnela, A.; Petaja, T.; Praplan, A. P.; Riccobono, F.; Rissanen, M. P.; Rondo, L.; Schobesberger, S.; Seinfeld, J. H.; Steiner, G.; Tome, A.; Trostl, J.; Winkler, P. M.; Williamson, C.; Wimmer, D.; Ye, P. L.; Baltensperger, U.; Carslaw, K. S.; Kulmala, M.; Worsnop, D. R.; Curtius, J., Neutral molecular cluster formation of sulfuric acid-dimethylamine observed in real time under atmospheric conditions. P Natl Acad Sci USA 2014, 111, (42), 15019-15024.

52. Schobesberger, S.; Junninen, H.; Bianchi, F.; Lonn, G.; Ehn, M.; Lehtipalo, K.; Dommen, J.; Ehrhart, S.; Ortega, I. K.; Franchin, A.; Nieminen, T.; Riccobono, F.; Hutterli, M.; Duplissy, J.; Almeida, J.; Amorim, A.; Breitenlechner, M.; Downard, A. J.; Dunne, E. M.; Flagan, R. C.; Kajos, M.; Keskinen, H.; Kirkby, J.; Kupc, A.; Kurten, A.; Kurten, T.; Laaksonen, A.; Mathot, S.; Onnela, A.; Praplan, A. P.; Rondo, L.; Santos, F. D.; Schallhart, S.; Schnitzhofer, R.; Sipila, M.; Tome, A.; Tsagkogeorgas, G.; Vehkamaki, H.; Wimmer, D.; Baltensperger, U.; Carslaw, K. S.; Curtius, J.; Hansel, A.; Petaja, T.; Kulmala, M.; Donahue, N. M.; Worsnop, D. R., Molecular understanding of atmospheric particle formation from sulfuric acid and large oxidized organic molecules. $P$ Natl Acad Sci USA 2013, 110, (43), 17223-17228.

53. Ehn, M.; Thornton, J. A.; Kleist, E.; Sipila, M.; Junninen, H.; Pullinen, I.; Springer, M.; Rubach, F.; Tillmann, R.; Lee, B.; Lopez-Hilfiker, F.; Andres, S.; Acir, I. H.; Rissanen, M.; Jokinen, T.; Schobesberger, S.; Kangasluoma, J.; Kontkanen, J.; Nieminen, T.; Kurten, T.; Nielsen, L. B.; Jorgensen, S.; Kjaergaard, H. G.; Canagaratna, M.; Dal Maso, M.; Berndt, T.; Petaja, T.; Wahner, A.; Kerminen, V. M.; Kulmala, M.; Worsnop, D. R.; Wildt, J.; Mentel, T. F., A large source of low-volatility secondary organic aerosol. Nature 2014, 506, (7489), 476-479.

54. Sarnela, N.; Jokinen, T.; Duplissy, J.; Yan, C.; Nieminen, T.; Ehn, M.; Schobesberger, S.; Heinritzi, M.; Ehrhart, S.; Lehtipalo, K.; Trostl, J.; Simon, M.; Kurten, A.; Leiminger, M.; Lawler, M. J.; Rissanen, M. P.; Bianchi, F.; Praplan, A. P.; Hakala, J.; Amorim, A.; Gonin, M.; Hansel, A.; Kirkby, J.; Dommen, J.; Curtius, J.; Smith, J. N.; Petaja, T.; Worsnop, D. R.; Kulmala, M.; Donahue, N. M.; Sipila, M., Measurement-model comparison of stabilized Criegee intermediate and highly oxygenated molecule production in the CLOUD chamber. Atmos Chem Phys 2018, 18, (4), 2363-2380.

55. Berndt, T.; Richters, S.; Jokinen, T.; Hyttinen, N.; Kurten, T.; Otkjaer, R. V.; Kjaergaard, H. G.; Stratmann, F.; Herrmann, H.; Sipila, M.; Kulmala, M.; Ehn, M., Hydroxyl radical-induced formation of highly oxidized organic compounds. Nat Commun 2016, 7, 13677.

56. Shilling, J. E.; Chen, Q.; King, S. M.; Rosenoern, T.; Kroll, J. H.; Worsnop, D. R.; McKinney, K. A.; Martin, S. T., Particle mass yield in secondary organic aerosol formed by the dark ozonolysis of alpha-pinene. Atmos Chem Phys 2008, 8, (7), 2073-2088.

57. Presto, A. A.; Donahue, N. M., Investigation of alpha-pinene plus ozone secondary organic aerosol formation at low total aerosol mass. Environ Sci Technol 2006, 40, (11), 3536-3543.

58. Ng, N. L.; Chhabra, P. S.; Chan, A. W. H.; Surratt, J. D.; Kroll, J. H.; Kwan, A. J.; McCabe, D. C.; Wennberg, P. O.; Sorooshian, A.; Murphy, S. M.; Dalleska, N. F.; Flagan, R. C.; Seinfeld, J. H., Effect of NOx level on secondary organic aerosol (SOA) formation from the photooxidation of terpenes. Atmos Chem Phys 2007, 7, (19), 5159-5174. 
753 59. Yu, F.; Luo, G.; Pryor, S. C.; Pillai, P. R.; Lee, S. H.; Ortega, J.; Schwab, J. J.; Hallar, A. G.;

754 Leaitch, W. R.; Aneja, V. P.; Smith, J. N.; Walker, J. T.; Hogrefe, O.; Demerjian, K. L., Spring

755 and summer contrast in new particle formation over nine forest areas in North America. Atmos

756 Chem Phys 2015, 15, (24), 13993-14003.

757 60. Chen, X. S.; Wang, Z. F.; Li, J.; Chen, H. S.; Hu, M.; Yang, W. Y.; Wang, Z.; Ge, B. Z.; Wang, 758 D. W., Explaining the spatiotemporal variation of fine particle number concentrations over Beijing 759 and surrounding areas in an air quality model with aerosol microphysics. Environ Pollut 2017, 231, $760 \quad 1302-1313$.

761 61. Elleman, R. A.; Covert, D. S., Aerosol size distribution modeling with the Community 762 Multiscale Air Quality modeling system in the Pacific Northwest: 3. Size distribution of particles 763 emitted into a mesoscale model. J Geophys Res-Atmos 2010, 115, D03204. 